\title{
Variability of polycyclic aromatic hydrocarbons and their oxidative derivatives in wintertime Beijing, China
}

\author{
Atallah Elzein $^{1}$, Rachel E. Dunmore ${ }^{1}$, Martyn W. Ward ${ }^{1}$, Jacqueline F. Hamilton ${ }^{1}$, and Alastair C. Lewis ${ }^{2}$ \\ ${ }^{1}$ Wolfson Atmospheric Chemistry Laboratories, Department of Chemistry, University of York, York, YO10 5DD, UK \\ ${ }^{2}$ National Centre for Atmospheric Science, University of York, York, YO10 5DD, UK
}

Correspondence: Atallah Elzein (atallah.elzein@york.ac.uk) and Alastair C. Lewis (ally.lewis@ncas.ac.uk)

Received: 5 February 2019 - Discussion started: 5 March 2019

Revised: 20 May 2019 - Accepted: 11 June 2019 - Published: 10 July 2019

\begin{abstract}
Ambient particulate matter (PM) can contain a mix of different toxic species derived from a wide variety of sources. This study quantifies the diurnal variation and nocturnal abundance of 16 polycyclic aromatic hydrocarbons (PAHs), 10 oxygenated PAHs (OPAHs) and 9 nitrated PAHs (NPAHs) in ambient PM in central Beijing during winter. Target compounds were identified and quantified using gas chromatography-time-of-flight mass spectrometry (GC-Q-ToF-MS). The total concentration of PAHs varied between 18 and $297 \mathrm{ng} \mathrm{m}^{-3}$ over $3 \mathrm{~h}$ daytime filter samples and from 23 to $165 \mathrm{ng} \mathrm{m}^{-3}$ in $15 \mathrm{~h}$ night-time samples. The total concentrations of PAHs over $24 \mathrm{~h}$ varied between 37 and $180 \mathrm{ng} \mathrm{m}^{-3}$ (mean: $97 \pm 43 \mathrm{ng} \mathrm{m}^{-3}$ ). The total daytime concentrations during high particulate loading conditions for PAHs, OPAHs and NPAHs were 224, 54 and $2.3 \mathrm{ng} \mathrm{m}^{-3}$, respectively. The most abundant PAHs were fluoranthene $\left(33 \mathrm{ng} \mathrm{m}^{-3}\right)$, chrysene $\left(27 \mathrm{ng} \mathrm{m}^{-3}\right)$, pyrene $\left(27 \mathrm{ng} \mathrm{m}^{-3}\right), \quad$ benzo[a]pyrene $\left(27 \mathrm{ng} \mathrm{m}^{-3}\right)$, benzo[b]fluoranthene $\left(25 \mathrm{ng} \mathrm{m}^{-3}\right)$, benzo[a]anthracene $\left(20 \mathrm{ng} \mathrm{m}^{-3}\right)$ and phenanthrene $\left(18 \mathrm{ng} \mathrm{m}^{-3}\right)$. The most abundant OPAHs were 9,10-anthraquinone $\left(18 \mathrm{ng} \mathrm{m}^{-3}\right)$, 1,8-naphthalic anhydride $\left(14 \mathrm{ng} \mathrm{m}^{-3}\right)$ and 9-fluorenone $\left(12 \mathrm{ng} \mathrm{m}^{-3}\right)$, and the three most abundant NPAHs were 9-nitroanthracene $\quad\left(0.84 \mathrm{ng} \mathrm{m}^{-3}\right), \quad 3$-nitrofluoranthene $\left(0.78 \mathrm{ng} \mathrm{m}^{-3}\right)$ and 3-nitrodibenzofuran $\left(0.45 \mathrm{ng} \mathrm{m}^{-3}\right)$. $\sum$ PAHs and $\sum$ OPAHs showed a strong positive correlation with the gas-phase abundance of $\mathrm{NO}, \mathrm{CO}, \mathrm{SO}_{2}$ and $\mathrm{HONO}$, indicating that PAHs and OPAHs can be associated with both local and regional emissions. Diagnostic ratios suggested emissions from traffic road and coal combustion were the predominant sources of PAHs in Beijing and also revealed the main source of NPAHs to be secondary photochemical
\end{abstract}

formation rather than primary emissions. $\mathrm{PM}_{2.5}$ and NPAHs showed a strong correlation with gas-phase HONO. 9Nitroanthracene appeared to undergo a photodegradation during the daytime and showed a strong positive correlation with ambient HONO $(R=0.90, P<0.001)$. The lifetime excess lung cancer risk for those species that have available toxicological data (16 PAHs, 1 OPAH and $6 \mathrm{NPAHs}$ ) was calculated to be in the range $10^{-5}$ to $10^{-3}$ (risk per million people ranges from 26 to 2053 cases per year).

\section{Introduction}

Outdoor air pollution contains a complex set of toxicological hazards and has become the largest detrimental environmental effect on human health (WHO, 2016). Exposure to outdoor high particulate loading of $\mathrm{PM}_{2.5}$ (aerodynamic diameter less than $2.5 \mu \mathrm{m}$ ) is linked to harmful health effects, particularly affecting urban populations (Raaschou-Nielsen et al., 2013; Hamra et al., 2014). The major sources of $\mathrm{PM}_{2.5}$ in urban areas are incomplete combustion or gas-particle conversion, and they contain a varied mix of chemicals including inorganic ions, organic carbon and elemental carbon (Bond et al., 2004; Saikawa et al., 2009). Polycyclic aromatic hydrocarbons (PAHs) and their oxidative derivatives (nitrated PAHs and oxygenated PAHs) are one class of species with high toxic potency (Nisbet and LaGoy, 1992; Larsen et al., 1998; Zhang et al., 2009; Jia et al., 2011; Wang et al., 2011a). PAHs released in the atmosphere come from both natural and anthropogenic sources; anthropogenic emissions include incomplete combustion of fossil fuels, agricultural burning and industrial and agricultural activities and are 
considered predominant (Ravindra et al., 2008; Zhang et al., 2009; Poulain et al., 2011; Kim et al, 2013; Abbas et al., 2018); natural contributions such as volcanic eruptions and forest fires are reported to be a less significant contributor to total emissions (Xu et al., 2006; Abbas et al, 2018).

Vapour-phase PAHs can undergo gas-phase reactions with oxidants in the atmosphere (including hydroxyl, ozone and nitrate radicals), leading to the generation of a range of nitrated PAHs and oxygenated PAHs (Atkinson et al., 1990; Atkinson and Arey, 1994; Sasaki et al., 1997). Atmospheric reaction with chlorine atoms in the presence of oxygen has also been suggested as a new formation pathway of OPAHs (Riva et al., 2015). OPAHs and NPAHs are often more toxic than the parent PAHs, showing a direct-acting mutagenicity on human cells (Durant et al., 1996; Hannigan et al., 1998; Purohit and Basu, 2000; Wang et al., 2011a; BenbrahimTallaa et al., 2012). Beside their formation in the gas phase, OPAHs and NPAHs can also be produced by heterogeneous reactions (Ringuet et al., 2012a, Jariyasopit et al., 2014; Zimmermann et al., 2013; Wenyuan and Zhu, 2014; Keyte et al., 2013). Many of these derivatives can also be linked to primary emissions from motor vehicles and combustion processes (Rogge et al., 1993, Albinet et al., 2007a; Jakober et al., 2007; Shen et al., 2012; Nalin et al., 2016).

Many studies in different countries have focused on studying toxic organic pollutants in $\mathrm{PM}_{2.5}$ because they fall within the respirable size range for humans (Sharma et al., 2007; Ringuet et al., 2012b, Farren et al., 2015). In the last decade, a major focus has been given to Chinese cities such as Shanghai, Beijing, Guangzhou, Tianjin and Shenzhen because of their population growth and geographic peripheral expansion in manufacturing capacity and energy industries which are located throughout each of the city's manufacturing zones.

This has made China the world leader in energy consumption but also the world's highest emitter of $\mathrm{PM}_{2.5}$ and PAHs (Lin et al., 2018; Zhang et al., 2009; Xu et al., 2006). The majority of previous studies have reported PAH concentrations in $24 \mathrm{~h}$ averaged samples during short-term and longterm measurement campaigns (Tomaz et al., 2016; Alves et al., 2017; Niu et al., 2017; Bandowe et al., 2014; Wang et al., 2011a). However, a long averaging period creates some limitations such as sampling artefacts, notably where changing atmospheric photolysis conditions (air humidity, temperature, wind direction, ozone or other oxidant concentrations) may have a significant influence on PAH concentrations and oxidation rates (Albinet et al., 2007b, 2009; Goriaux et al., 2006; Tsapakis and Stephanou, 2003, 2007; Ringuet et al., 2012b). More intensive and higher frequency measurements in field campaigns have been suggested as a means to improve the positive matrix factorization model performance (Tian et al., 2017; Srivastava et al., 2018). A few studies have used twice daily (12 h) sampling (Albinet et al., 2008; Zhang et al., 2018; Farren et al., 2015; Ringuet et al., 2012b), obtaining limited information on variability in concentrations during the daytime and night-time (Tsapakis and Stephanou,
2007). Shorter time periods for sampling ( 3 and $4 \mathrm{~h}$ ) are still very limited (Reisen and Arey, 2004; Srivastava et al., 2018). Considering the above, this paper determines the temporal diurnal and nocturnal variation of the $\mathrm{PM}_{2.5}$-bound concentrations of PAHs, OPAHs and NPAHs from the air of Beijing in China, it shows the role of photochemistry in the formation of OPAHs and NPAHs, and it associates the fate and evolution of PAHs, OPAHs and NPAHs with the gas-phase concentrations of other pollutants $\left(\mathrm{O}_{3}, \mathrm{CO}, \mathrm{NO}, \mathrm{NO}_{2}, \mathrm{SO}_{2}\right.$, HONO). The cancer risk associated with inhalation of $\mathrm{PM}_{2.5}$ was also calculated. This paper explores the feasibility of higher frequency sampling in Beijing, to support the identification of emissions sources from diagnostic ratios and correlations with atmospheric gas pollutants. These measurements also raise the potential importance of the chemical relationship between NPAHs and HONO, which may impact the HONO budget in the atmosphere and, if included, improve related models. This study comes 3 years after declaring the anti-pollution action plan and strategy taken by the municipal government of Beijing and published in September 2013 (Ministry of Ecology and Environment The People's Republic of China, 2013), trying to increase the number of days with good air quality index by prohibiting coal combustion, promoting clean energy vehicles and public transport, helping industrial transformation and upgrading to new technologies.

\section{Experimental steps}

\subsection{Sampling site and method}

The sampling setup shown in Fig. S1 in the Supplement was located at the Institute of Atmospheric Physics, Chinese Academy of Sciences in Beijing $\left(39^{\circ} 58^{\prime} 28^{\prime \prime} \mathrm{N}\right.$, $\left.116^{\circ} 22^{\prime} 15^{\prime \prime} \mathrm{E}\right)$ as part of the Air Pollution and Human Health $(\mathrm{APHH})$ research programme. $\mathrm{PM}_{2.5}$ filter samples were collected on the roof of a two-storey building about $8 \mathrm{~m}$ above ground level using a high-volume air sampler (Ecotech HiVol 3000 , Victoria, Australia) operating at $1.33 \mathrm{~m}^{3} \mathrm{~min}^{-1}$. Daytime particles were collected every $3 \mathrm{~h}$ during high PM concentration levels, $9 \mathrm{~h}$ at low PM levels and over $15 \mathrm{~h}$ at nighttime during 18 continuous days (22 November to 9 December 2016). In total 57 samples were collected. The daytime sampling started at 08:30 (China standard time), and the filter was changed every $3 \mathrm{~h}$. During low particulate loading conditions, the daytime sampling started at 08:30 for a sampling duration of $9 \mathrm{~h}$. Night-time sampling began at $\sim 17: 30$ and ended at 08:30 the following day. Prior to sampling, the quartz filters $(20.3 \mathrm{~cm} \times 25.4 \mathrm{~cm}$ ) (supplied by Whatman, Maidstone, UK) were baked at $550^{\circ} \mathrm{C}$ for $5 \mathrm{~h}$ in order to eliminate any organic matter. After sampling, filters were wrapped in aluminium foil, sealed in polyethylene bags and stored at $-20^{\circ} \mathrm{C}$ until extraction and analysis. 


\subsection{Extraction method and clean-up}

All collected samples were extracted using an Accelerated Solvent Extractor automated system (Dionex, ASE 350 ). Prior to extraction, $1 / 16$ (surface area equivalent to $25.7 \mathrm{~cm}^{2}$ ) of each filter was cut using a hole puncher $(\varnothing=27 \mathrm{~mm})$, and for each batch of six samples, one sample was spiked with a mixture of two deuterated PAHs (phenanthrene-d10; pyrene-d10), two deuterated-OPAHs (9fluorenone-d8; 9,10-anthraquinone-d8) and two deuterated NPAHs (1-nitronaphthalene-d7; 3-nitrofluoranthene-d9), as surrogate standards for PAHs, OPAHs and NPAHs, respectively, with concentration on filters corresponding to $400 \mathrm{ng}$ (40 $\mu \mathrm{L}, 10 \mathrm{ng} \mu \mathrm{L}^{-1}$ in acetonitrile). All punched samples were cut into small pieces and packed into $5 \mathrm{~mL}$ stainless steel extraction cells. Extractions were carried out in acetonitrile as follows: oven at $120^{\circ} \mathrm{C}$, pressure at $1500 \mathrm{psi}$, rinse volume $60 \%$ and $60 \mathrm{~s}$ purge time for three consecutive 5 min cycles. Extracts $(V=20 \mathrm{~mL})$ were evaporated to approximately $6 \mathrm{~mL}$ under a gentle stream of nitrogen before the clean-up step. All samples and blanks were purified on a SPE silica normal-phase cartridge $(1 \mathrm{~g} / 6 \mathrm{~mL}$; Sigma Aldrich) to reduce the impacts of interfering compounds in the matrix and to help maintain a clean gas chromatograph (GC) injection inlet liner. After the clean-up step, the solution of each sample was evaporated to $1 \mathrm{~mL}$ under a gentle stream of nitrogen at room temperature $\left(20^{\circ} \mathrm{C}\right)$ and transferred to a $1.5 \mathrm{~mL}$ autosampler amber vial. Each concentrated sample was stored at $4{ }^{\circ} \mathrm{C}$ until analysis. The average recovery efficiencies calculated from surrogate standards ranged from $85 \%$ to $96 \%$ (phenanthrene-d10: $95 \pm 9 \%$; pyrene-d10: $101 \pm 7 \%$; 9-fluorenone-d8: $98 \pm 13 \%$; 9,10anthraquinone-d8: $102 \pm 11 \%$; 1-nitronaphthalene-d7: $93 \pm$ $8 \%$; 3-nitrofluoranthene-d9: $101 \pm 11 \%$ ), and the target compounds concentrations were calculated incorporating measured recovery efficiencies.

\subsection{Chemical standards}

The chemical compounds that have attracted the most attention in previous studies are the 16 priority PAHs and their derivatives, defined by the United States Environment Protection Agency (EPA). The choice of the organic compounds investigated in this study is based on those associated with the particle phase and commercially available standards. All compounds are listed in Table 1 and were purchased from Sigma Aldrich, Alfa Aesar and Santa Cruz Biotechnology in the UK and had a minimum purity of $98 \%$. In parallel to individual standards, a mixed solution of the 16 EPA PAHs (CRM47940, Supelco, Sigma Aldrich) of $10 \mu \mathrm{g} \mathrm{mL}^{-1}$ in acetonitrile was also used. Standard solutions for calibrations were prepared in acetonitrile (HPLC grade, 99.9\% purity, Sigma Aldrich). Deuterated compounds were supplied by $\mathrm{C} / \mathrm{D} / \mathrm{N}$ isotopes and distributed by QMX Laboratories Ltd (Essex, UK).

\subsection{Gas chromatography-mass spectrometry analysis}

Target compounds were quantified using an Accurate-Mass Quadrupole Time-of-Flight GC/MS system (GC Agilent 7890B coupled to an Agilent 7200 Q-ToF-MS). Parent PAHs were separated in a $35 \mathrm{~min}$ analysis time using a capillary HP-5MS Ultra Inert GC column (Agilent; $5 \%$ phenyl substituted methylpolysiloxane; length: $30 \mathrm{~m}$, diameter: $0.25 \mathrm{~mm}$, film thickness: $0.25 \mu \mathrm{m})$. Inlet injections of $1 \mu \mathrm{L}$ were performed in pulsed splitless mode at $320^{\circ} \mathrm{C}$ using an automated liquid injection with the GERSTEL MultiPurpose Sampler (MPS). Helium was used as a carrier gas at $1.4 \mathrm{~mL} \mathrm{~min}^{-1}$. The GC oven temperature was programmed to $65^{\circ} \mathrm{C}$ for $4 \mathrm{~min}$ as a starting point and then increased to $185^{\circ} \mathrm{C}$ at a heating rate of $40^{\circ} \mathrm{C} \mathrm{min}^{-1}$ and held for $0.5 \mathrm{~min}$, followed by a heating rate of 10 to $240^{\circ} \mathrm{C}$ and then ramped at $5^{\circ} \mathrm{C} \mathrm{min}^{-1}$ until $320^{\circ} \mathrm{C}$ and held isothermally for a further $6 \mathrm{~min}$ to ensure all analytes eluted from the column. The mass spectrometer (MS) was operated in electron ionization (EI) mode at $70 \mathrm{eV}$ with an emission current of $35 \mu \mathrm{A}$. Calibration solutions were injected three times in the same sequence for samples and covered the range from 1 to

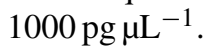

The method development for OPAHs and NPAHs was based on previous studies (Albinet et al., 2006, 2014; Bezabeh et al., 2003; Kawanaka et al., 2007) using negative chemical ionization (NCI) performed at $155 \mathrm{eV}$ and $48 \mu \mathrm{A}$, with methane $\left(\mathrm{CH}_{4}\right.$; research grade 5.5 , Air Liquide) as reagent gas. Target compounds were eluted using the $\mathrm{RXi}$ $5 \mathrm{~ms}$ (Restek GC column) with similar phase and characteristics to HP-5ms. Analysis was performed in $29.2 \mathrm{~min}$, and the GC settings were as follows: $1 \mu \mathrm{L}$ of each sample was injected in pulsed splitless mode at $310^{\circ} \mathrm{C}$; helium flow was set to $1.2 \mathrm{~mL} \mathrm{~min}^{-1}$; the initial oven temperature of $70^{\circ} \mathrm{C}$ was held for $4 \mathrm{~min}$, followed by a heating rate of $60^{\circ} \mathrm{C} \mathrm{min}-1$ until $190^{\circ} \mathrm{C}$, which was then raised to $270^{\circ} \mathrm{C}$ at a rate of $25^{\circ} \mathrm{C} \mathrm{min}{ }^{-1}$, ending with $5^{\circ} \mathrm{C} \mathrm{min}^{-1}$ until $320^{\circ} \mathrm{C}$, held for $10 \mathrm{~min}$. A 10 -point calibration curve within the range 0.5 to $1000 \mathrm{pg} \mathrm{LL}^{-1}$ was obtained with the correlation coefficients from the linear regression from 0.980 to 0.999 .

\subsection{Data analysis and error evaluation}

Data were recorded and processed using the Agilent Qualitative and Quantitative analysis software. Target compounds were isolated using extracted-ion chromatograms (EICs) and identified by the combination of retention time and mass spectral match against the calibration standards measured simultaneously within the samples. The limit of detection (LOD) was defined as the valid lowest measurable peak response to peak noise near the elution time of the target peak $(S / N=3)$ in a mix of standard solutions. As the chemical noise increases during the analysis of real samples, the limit of quantification (LOQ) was defined $S / N=10$. These recommendations are in accordance with previous analyti- 
Table 1. List of measured PAHs, OPAHs and NPAHs and their abbreviations. Compounds are listed in order of elution. \%RSD refers to the relative standard deviation.

\begin{tabular}{|c|c|c|c|c|}
\hline \multirow{2}{*}{$\begin{array}{l}\text { Compound/formula } \\
16 \text { PAHs }\end{array}$} & \multirow[t]{2}{*}{ Abbreviation } & \multirow{2}{*}{$\frac{\text { Accurate mass }(\mathrm{m} / \mathrm{z})}{\text { Monitored ions in EI mode }}$} & \multicolumn{2}{|c|}{$\%$ RSD } \\
\hline & & & Inter-day & Intra-day \\
\hline Naphthalene $/ \mathrm{C}_{10} \mathrm{H}_{8}$ & NAP & $128.0628-127.0543-102.0464$ & 4.6 & 3.2 \\
\hline Acenaphthylene $/ \mathrm{C}_{12} \mathrm{H}_{8}$ & $\mathrm{ACY}$ & $152.0629-151.0546-126.0463$ & 4.1 & 2.1 \\
\hline Acenaphthene $/ \mathrm{C}_{12} \mathrm{H}_{10}$ & $\mathrm{AC}$ & $153.0705-154.0779-152.0634$ & 5.5 & 6.1 \\
\hline Fluorene $/ \mathrm{C}_{13} \mathrm{H}_{10}$ & FLU & $166.0782-165.0708-164.0621$ & 4.0 & 2.9 \\
\hline Phenanthrene $/ \mathrm{C}_{14} \mathrm{H}_{10}$ & PHE & $178.0789-176.0626-152.0622$ & 4.6 & 3.0 \\
\hline Anthracene $/ \mathrm{C}_{14} \mathrm{H}_{10}$ & ANT & $178.0787-176.0627-152.0620$ & 4.7 & 4.2 \\
\hline Fluoranthene $/ \mathrm{C}_{16} \mathrm{H}_{10}$ & FLT & $202.0788-200.0626-101.0388$ & 1.8 & 4.5 \\
\hline Pyrene $/ \mathrm{C}_{16} \mathrm{H}_{10}$ & PYR & $202.0788-200.0626-101.0389$ & 3.2 & 1.9 \\
\hline Benzo[a]anthracene $/ \mathrm{C}_{18} \mathrm{H}_{12}$ & $\mathrm{BaA}$ & $228.0927-226.0783-101.0388$ & 6.2 & 1.2 \\
\hline Chrysene $/ \mathrm{C}_{18} \mathrm{H}_{12}$ & CHR & $228.0943-226.0784-101.0387$ & 6.0 & 2.6 \\
\hline Benzo[b]fluoranthene $/ \mathrm{C}_{20} \mathrm{H}_{12}$ & $\mathrm{BbF}$ & $252.0941-250.0784-126.0467$ & 4.7 & 2.0 \\
\hline Benzo[k]fluoranthene $/ \mathrm{C}_{20} \mathrm{H}_{12}$ & $\mathrm{BkF}$ & $252.0940-250.0783-126.0468$ & 8.9 & 8.7 \\
\hline Benzo[a]pyrene $/ \mathrm{C}_{20} \mathrm{H}_{12}$ & $\mathrm{BaP}$ & $252.0940-250.0783-126.0466$ & 5.2 & 2.3 \\
\hline Indeno[1,2,3-cd]pyrene $/ \mathrm{C}_{22} \mathrm{H}_{12}$ & IcdP & $276.0939-274.0783-138.0467$ & 7.2 & 2.6 \\
\hline Dibenz[a, h]anthracene $/ \mathrm{C}_{22} \mathrm{H}_{14}$ & DahA & $278.1097-276.0941-139.0545$ & 7.7 & 4.3 \\
\hline Benzo[ghi]perylene $/ \mathrm{C}_{22} \mathrm{H}_{12}$ & BghiP & $276.0942-274.0783-138.0467$ & 5.4 & 2.6 \\
\hline 10 OPAHs & & Monitored ions in NCI mode & & \\
\hline 1,4-Naphtoquinone $/ \mathrm{C}_{10} \mathrm{H}_{6} \mathrm{O}_{2}$ & 1,4-NAQ & 158.0420 & 6.3 & 5.1 \\
\hline 1-Naphthaldehyde $/ \mathrm{C}_{11} \mathrm{H}_{8} \mathrm{O}$ & 1-NALD & 156.0557 & 8.9 & 7.8 \\
\hline 9-Fluorenone $/ \mathrm{C}_{13} \mathrm{H}_{8} \mathrm{O}$ & 9-FLON & 180.0639 & 5.7 & 6.2 \\
\hline 9,10-Anthraquinone $/ \mathrm{C}_{14} \mathrm{H}_{8} \mathrm{O}_{2}$ & 9,10-ANQ & 208.0572 & 5.6 & 3.2 \\
\hline 1,8-Naphthalicanhydride $/ \mathrm{C}_{12} \mathrm{H}_{6} \mathrm{O}_{3}$ & $1,8-\mathrm{NANY}$ & 198.0436 & 6.4 & 5.6 \\
\hline Phenanthrene-9-carboxaldehyde $/ \mathrm{C}_{15} \mathrm{H}_{10} \mathrm{O}$ & PHCA & 206.0777 & 5.4 & 4.9 \\
\hline Benzo[a]fluorenone $/ \mathrm{C}_{17} \mathrm{H}_{10} \mathrm{O}$ & $\mathrm{BaFLU}$ & 230.0791 & 6.4 & 3.2 \\
\hline 7H-Benz[de]anthracene-7-one $/ \mathrm{C}_{17} \mathrm{H}_{10} \mathrm{O}$ & BANTone & 230.0781 & 7.2 & 5.8 \\
\hline 1-Pyrenecaboxaldehyde $/ \mathrm{C}_{17} \mathrm{H}_{10} \mathrm{O}$ & 1-PYRCA & 230.0786 & 7.5 & 7.2 \\
\hline 1,2-Benzanthraquinone $/ \mathrm{C}_{18} \mathrm{H}_{10} \mathrm{O}_{2}$ & 1,2-BANQ & 258.0743 & 8.5 & 7.4 \\
\hline 9 NPAHs & & Monitored ions in NCI mode & & \\
\hline 1-Nitronaphthalene $/ \mathrm{C}_{10} \mathrm{H}_{7} \mathrm{NO}_{2}$ & 1-NNAP & 173.0551 & 4.7 & 4.4 \\
\hline 3-Nitrodibenzofuran $/ \mathrm{C}_{12} \mathrm{H}_{7} \mathrm{NO}_{3}$ & 3-NDBF & 213.0475 & 4.4 & 5.1 \\
\hline 5-Nitroacenaphthene $/ \mathrm{C}_{12} \mathrm{H}_{9} \mathrm{NO}_{2}$ & 5-NAC & 199.0682 & 5.6 & 5.3 \\
\hline 2-Nitrofluorene $/ \mathrm{C}_{13} \mathrm{H}_{9} \mathrm{NO}_{2}$ & 2-NFLU & 211.0689 & 5.0 & 5.4 \\
\hline 9-Nitroanthracene $/ \mathrm{C}_{14} \mathrm{H}_{9} \mathrm{NO}_{2}$ & 9-NANT & 223.0697 & 5.9 & 3.9 \\
\hline 3-Nitrofluoranthene $/ \mathrm{C}_{16} \mathrm{H}_{9} \mathrm{NO}_{2}$ & 3-NFLT & 247.0688 & 6.4 & 4.1 \\
\hline 1-Nitropyrene $/ \mathrm{C}_{16} \mathrm{H}_{9} \mathrm{NO}_{2}$ & 1-NPYR & 247.0691 & 3.9 & 3.2 \\
\hline 6-Nitrochrysene $/ \mathrm{C}_{18} \mathrm{H}_{11} \mathrm{NO}_{2}$ & 6-NCHR & 273.0847 & 4.7 & 5.4 \\
\hline 6-Nitrobenzo[a]pyrene $/ \mathrm{C}_{20} \mathrm{H}_{11} \mathrm{NO}_{2}$ & 6-NBaP & 297.0845 & 8.4 & 9.7 \\
\hline
\end{tabular}

cal studies (Nyiri et al., 2016; Ramírez et al., 2015). LOD values were evaluated from standard solutions and ranged between 1 and $20 \mathrm{pg}$ for PAHs, 0.01 and $0.2 \mathrm{pg}$ (except 1-naphthaldehyde $0.5 \mathrm{pg}$ ) for OPAHs and 0.02 to $0.25 \mathrm{pg}$ for NPAHs.

To determine any sources of contamination during sample preparation and the analytical procedure, the solvent (acetonitrile) and field blanks $(n=2)$ were analysed following the same procedure as for the samples (extraction, SPE, evaporation). Most target compounds were found to be below LOD $(S / N=3)$ or orders of magnitude (up to $10^{3}-10^{4}$ ) lower than was found in the samples. A small number of compounds found in field blanks (1,8-naphthalic anhydride, benzo[a]fluorenone, 1-nitronaphthalene, 9-nitroanthracene) have a higher contribution $(4 \%-30 \%)$ to very few filters (two to five samples) collected over a $3 \mathrm{~h}$ time period, if this was coincident with low particulate loading conditions. The contribution to each compound from field blanks was corrected in the final data.

We evaluated the precision of the method by calculating the relative standard deviation (\%RSD) from replicate analysis as shown in Table 1. For PAHs, the precision of sam- 

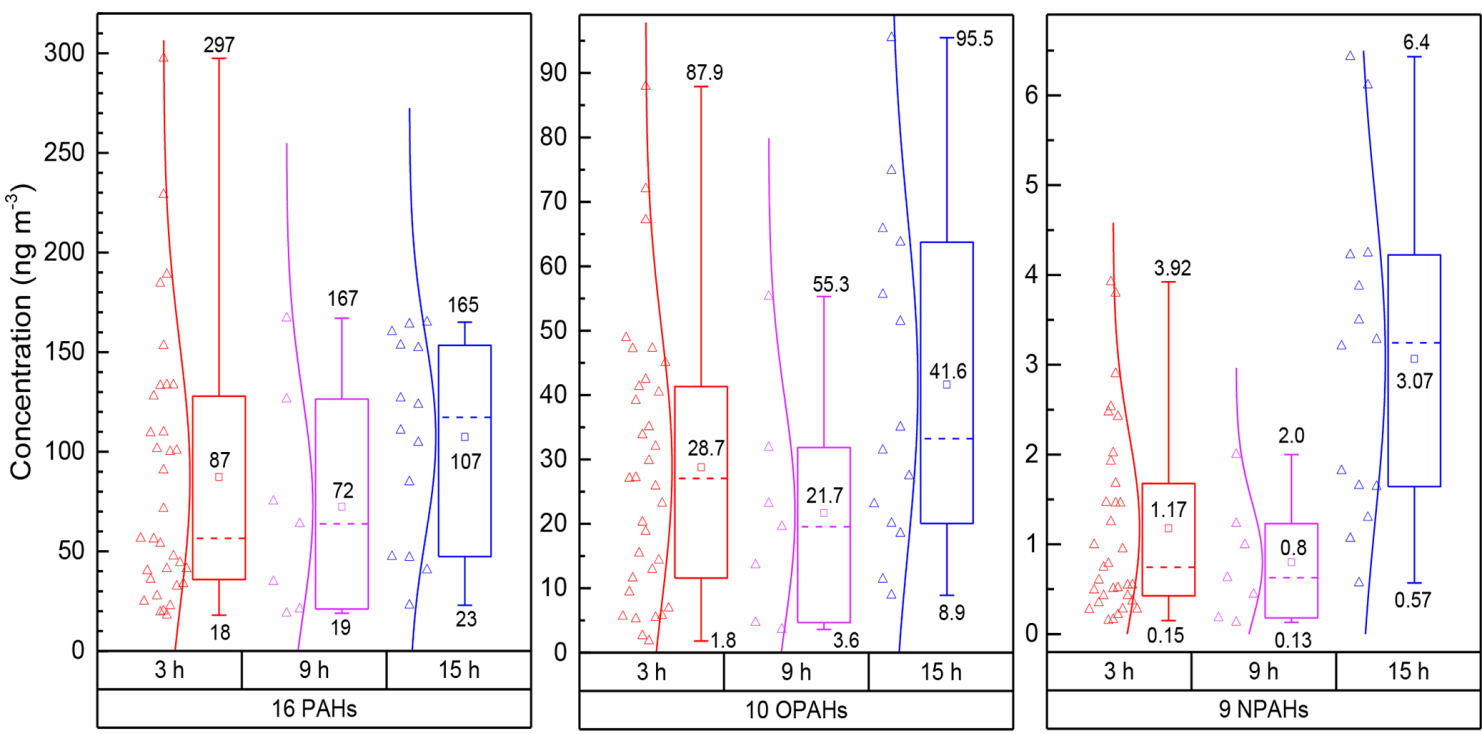

Figure 1. Concentrations of $\sum$ PAHs, $\sum$ OPAHs and $\sum$ NPAHs in $\mathrm{PM}_{2.5}$ samples during the daytime (3, $\left.9 \mathrm{~h}\right)$ and night-time (15 h). The box plot represents the 25th and 75th percentiles range of the observed concentrations, and the bottom and top lines indicate minimum and maximum concentrations. Square symbols represent the mean concentration, and the short dashed line within the boxes represents the median. Empty triangles correspond to the data measured over 3, 9 and $15 \mathrm{~h}$ samples. The lines between data points and boxes reflect a normal distribution curve.

ple replicates $(n=10)$ during inter-day and intra-day varied from $1.8 \%$ to $8.9 \%$ (mean $5.2 \%$ ) and $1.2 \%$ to $8.7 \%$ (mean $3.4 \%$ ), respectively. The \%RSD average for deuterium labelled compounds was about $3.6 \%$. For OPAHs and NPAHs, two different concentrations of standards were analysed (50 pg; $n=6$ and $400 \mathrm{pg} ; n=6$ ); inter-day precision of 10 OPAHs gives an average \%RSD of $6.8 \%$ (range: $5.4 \%-$ $8.9 \%)$ and intra-day precision of $5.6 \%(3.2 \%-7.8 \%)$. Similar to OPAHs, repeatability and reproducibility between days for NPAHs varied from $3.9 \%$ to $8.4 \%$ (mean $5.5 \%$ ) and $3.2 \%$ to $9.7 \%$ (mean $5.2 \%$ ), respectively. Hence, the estimated random error quantified by the standard deviation of the measurements did not exceed $7 \%$ on average. The systematic error may be due to the influence of the sample matrix during the analysis sequence on the quantification step and the calibration offset. It was estimated to be a maximum $10 \%$ from the measured recovery of the deuterium species (Garrido-Frenich et al., 2006). Therefore, the overall estimated error, combining the precision and the systematic effects, is less than $20 \%$.

Another source of error can be attributed to sampling artefacts, and this has been discussed in previous studies (Schauer et al., 2003; Goriaux et al., 2006; Tsapakis and Stephanou, 2003). The absence of an ozone denuder to trap the gas-phase oxidants may lead to an underestimation of the true values of PAHs due to chemical decomposition. Therefore, data from long sampling times and under high ozone ambient concentrations may be biased by sampling artefacts by more than $100 \%$ (Schauer et al., 2003; Goriaux et al., 2006). However, at low ozone levels, negative artefacts were considered not significant (Tsapakis and Stephanou, 2003), whilst, at medium ozone levels (30-50 ppb), PAH values were underestimated by $30 \%$ (Schauer et al., 2003). In addition, heterogeneous reactions during particle sampling may occur only on the monolayer surface coverage with limited diffusion of oxidants to the bulk particles (Keyte et al., 2013, and references therein). Previous studies reported that the formation of NPAHs during high-volume sampling is not significant and calculated to be $<3 \%$ (Arey et al., 1988) and $<0.1 \%$ (Dimashki et al., 2000).

Considering the role of ozone (always below $30 \mathrm{ppb}$ in this study, with a mean value of $10.4 \pm 8.8 \mathrm{ppb}$ ), in addition to sampling time and temperature, the estimation of the negative sampling artefacts on our data ranges between $10 \%$ and $20 \%$, with the highest error estimation attributable to the longest sampling time $(15 \mathrm{~h})$.

\section{Results and discussion}

\subsection{Temporal variations of PAHs, OPAHs and NPAHs in $\mathbf{P M}_{2.5}$}

The volume of literature on $\mathrm{PM}_{2.5}$ has rapidly increased over the last two decades, and various disciplines have contributed to improve understanding about source emissions, chemical composition and impact on people's behaviour and health. In China, the official air quality guidelines for $\mathrm{PM}_{2.5}$ expressed as an annual mean and $24 \mathrm{~h}$ average are 35 and $75 \mu \mathrm{g} \mathrm{m}^{-3}$, respectively (WHO, 2016; Ministry of Ecology and Environment The People's Republic of China, 2012). During the 
sampling period of this study (November-December 2016), $\mathrm{PM}_{2.5}$ was measured every hour and ranged from 3.8 to $438 \mu \mathrm{g} \mathrm{m}^{-3}$, with an average concentration of $103 \mu \mathrm{g} \mathrm{m}^{-3}$. The average $24 \mathrm{~h} \mathrm{PM}_{2.5}$ concentration was $108 \pm 82 \mu \mathrm{g} \mathrm{m}^{-3}$ (range: $10-283 \mu \mathrm{g} \mathrm{m}^{-3}$ ), exceeding the $24 \mathrm{~h}$ limit value on 10 of the 18 sampling days. Concurrent $\mathrm{PM}_{2.5}$ concentrations were averaged to the filter sampling times $(3,9,15 \mathrm{~h})$ and are shown in Figs. 6 and S3. The daily $(24 \mathrm{~h})$ concentration of benzo[a]pyrene ranged from 4.46 to $29.8 \mathrm{ng} \mathrm{m}^{-3}$ (average $15 \pm 8.9 \mathrm{ng} \mathrm{m}^{-3}$ ), exceeding the $24 \mathrm{~h}$ average limit value of $2.5 \mathrm{ng} \mathrm{m}^{-3}$ for China (Ministry of Ecology and Environment The People's Republic of China, 2012) on all of the 18 days of the sampling period.

Figure 1 shows the measured concentrations of PAHs in the $3 \mathrm{~h}$ daytime samples ranging from 18 to $297 \mathrm{ng} \mathrm{m}^{-3}$ (average $87.3 \pm 58 \mathrm{ng} \mathrm{m}^{-3}$ ) and from 23 to $165 \mathrm{ng} \mathrm{m}^{-3}$ (average $107 \pm 51 \mathrm{ng} \mathrm{m}^{-3}$ ) in the $15 \mathrm{~h}$ night-time samples. The $24 \mathrm{~h}$ total concentrations (combined results from daytime and night-time samples) of the 16 PAHs varied between 37 and $180 \mathrm{ng} \mathrm{m}^{-3}$ (average $97 \pm 43 \mathrm{ng} \mathrm{m}^{-3}$ ). PAH derivatives showed the following trends: total OPAH concentrations varied from 3.3 to $55 \mathrm{ng} \mathrm{m}^{-3}$ (average: $26 \pm 16 \mathrm{ng} \mathrm{m}^{-3}$ ) in daytime and from 8.9 to $95 \mathrm{ng} \mathrm{m}^{-3}$ (average: $41.6 \pm$ $26 \mathrm{ng} \mathrm{m}^{-3}$ ) at night-time; OPAHs were approximately 25 and 14 times higher than average NPAHs in the daytime (average: $1.03 \pm 0.74 \mathrm{ng} \mathrm{m}^{-3}$, range: $0.13-2.3$ ) and night-time (average: $3.06 \pm 1.8 \mathrm{ng} \mathrm{m}^{-3}$, range: $0.57-6.43$ ), respectively.

PHE (see Table 1 for abbreviations), FLT, PYR, BaA, $\mathrm{CHR}, \mathrm{BbF}$ and $\mathrm{BaP}$ were the largest contributors to the total PAH concentration. 9-FLON, 9,10-ANQ and 1,8-NANY were the three major O-PAH species. The most abundant NPAHs were 3-NDBF, 9-NANT and 3-NFLT. The temporal profile and contributions of each compound to the total concentration are shown in Fig. 2 and detailed in Table 2 . The highest concentrations recorded in this study were on the day of 29 November 2016; concentrations of all target compounds in the particulate phase are displayed in Fig. S2. Some nitro compounds (5-NAC, 1-NPYR, 6-NCHR, 6-NBaP) were below LOQ in a few samples, while one oxy compound (1,8-naphthalic anhydride) was outside the dynamic range and limit of linearity of the calibration curve for samples with high mass loading (Table 2). Similar dominant compounds were found in different cities (Xi' an, Jinan, Beijing) of China (Bandowe et al., 2014; Zhang et al., 2018; Wang et al., 2011c). The average $24 \mathrm{~h}$ total PAH concentration $\left(97 \mathrm{ng} \mathrm{m}^{-3}\right)$ in this study was higher than the average value reported for Guangzhou in the south of China (average $45.5 \mathrm{ng} \mathrm{m}^{-3}$, from Liu et al., 2015); however, it was lower than average values reported for Xi' an in winter (range 14-701 $\mathrm{ng} \mathrm{m}^{-3}$; average $206 \mathrm{ng} \mathrm{m}^{-3}$ from Wang et al., 2006) and in the suburbs of Beijing in winter (average $277 \mathrm{ng} \mathrm{m}^{-3}$, from Feng et al., 2005). Our average value $\left(97 \mathrm{ng} \mathrm{m}^{-3}\right)$ was comparable to the reported values in a recent study (Feng et al., 2019) at the campus of Peking University Health Science Center, a short distance from our sampling site $(\sim 1$ mile), where the authors reported a total PAH average concentration in winter Beijing (2014-2015) of $88.6 \pm 75 \mathrm{ng} \mathrm{m}^{-3}$. The lower average concentration of total PAHs reported in this study and Feng et al. (2019) can potentially be attributed to the efforts by the municipal government to improve air quality and control emissions by reducing combustion sources in the years of intervention. The urban location in this study (Fig. S1) was surrounded by busy roads, residential buildings, an underground railway and restaurants and, further afield, thermal power stations. PAH concentrations are anticipated to decline closer to the mountains in the north and west of Beijing due to the air mass trajectory, ageing and distance from emission sources. Results from this study can be considered representative (within the margin of error) of the urban area of Beijing including districts such as Chaoyang, Haidian, Fengtai, Xicheng, Dongcheng and Shijingshan, covering an approximate population of 12 million. Future studies in less populated districts and different areas of the metropolitan of Beijing would be helpful for comparison of population exposure.

Concentrations of PAHs in $\mathrm{PM}_{10}$ (range: 3.2$222.7 \mathrm{ng} \mathrm{m}^{-3}$ ) in Beijing were found in previous studies to be lower than in $\mathrm{PM}_{2.5}$ (Wang et al., 2011c). The concentration of PAHs in this study was much lower than that reported in certain other megacities, for example, Delhi, India, in the winter season of 2003 (range: $948-1345 \mathrm{ng} \mathrm{m}^{-3}$; mean: $1157 \pm 113 \mathrm{ng} \mathrm{m}^{-3}$ from Sharma et al., 2007) and Mexico City, Mexico, in October 2002 (range: 60-910 $\mathrm{ng} \mathrm{m}^{-3}$; mean: $310 \mathrm{ng} \mathrm{m}^{-3}$ from Marr et al., 2004). Average concentrations for total PAHs in the first $3 \mathrm{~h}$ filter of the day (08:30-11:30; Monday to Friday; mean: $112 \mathrm{ng} \mathrm{m}^{-3}$ ) were 1.5 times higher than the rest of the day and 1.6 times higher than the same first $3 \mathrm{~h}$ on a Sunday. A potential reason for the elevated concentrations in the morning hours is the rush hour traffic during working days, coupled with a period of a shallow boundary layer.

The mean total concentrations in Table 2 for the $3 \mathrm{~h}$ integration samples of OPAHs and NPAHs were $28.7 \pm$ $21 \mathrm{ng} \mathrm{m}^{-3}$ (range: $1.8-87.9 \mathrm{ng} \mathrm{m}^{-3}$ ) and $1.17 \pm 1 \mathrm{ng} \mathrm{m}^{-3}$ (range: $0.15-3.92 \mathrm{ng} \mathrm{m}^{-3}$ ). Average night-time concentrations were $41.6 \mathrm{ng} \mathrm{m}^{-3}$ (OPAHs) and $3.06 \mathrm{ng} \mathrm{m}^{-3}$ (NPAHs), 2.6 and 35 times lower than the average total PAHs in the night samples. The ratios of mean concentrations of PAHs divided by the concentration of OPAHs and NPAHs for the $3 \mathrm{~h}$ samples were 3 and 74 . Ratios of combined daytime and night-time samples $(24 \mathrm{~h}$ ) were on average 2.9 (range 1.9-4.6) for $\sum$ PAHs / $\sum$ OPAHs and 47.4 (range 25-79) for $\sum$ PAHs / $\sum$ NPAHs. Lower ratios were reported from a winter study in Xi' an, China, where $\sum$ PAHs / $\sum$ OPAHs ranged from 1.75 to 1.86 , and $\sum$ PAHs / $\sum$ NPAHs ranged from 34 to 55.2. On the other hand, similar trends to our study were recorded for $\sum$ PAHs / $\sum$ OPAHs in Europe, such as Athens in Greece in winter (ratio 28.9/6.9=4.2) (Andreou and Rapsomanikis, 2009) and Augsburg in Germany in winter (ratio 11/3.2 = 3.4) (Pietrogrande et al., 2011). Further 
Table 2. Minimum, maximum and average atmospheric concentrations of PAHs, OPAHs and NPAHs in PM 2.5 . Compounds in bold represent the highest mean contribution to the sum of all compounds.

\begin{tabular}{|c|c|c|c|}
\hline \multirow[t]{2}{*}{ Compound } & \multicolumn{2}{|c|}{ Concentrations $\left(\mathrm{ng} \mathrm{m}^{-3}\right)$} & \multirow{2}{*}{$\begin{array}{c}\text { Average contribution } \\
\text { to total }(\%)\end{array}$} \\
\hline & Minimum-maximum & Average & \\
\hline 16 PAHs & $(3 \mathrm{~h}) /(9 \mathrm{~h}) /(15 \mathrm{~h})$ & $\left(3 \mathrm{~h} \pm \mathrm{SD}^{*}\right) /(9 \mathrm{~h} \pm \mathrm{SD}) /(15 \mathrm{~h} \pm \mathrm{SD})$ & $(3 \mathrm{~h}) /(9 \mathrm{~h}) /(15 \mathrm{~h})$ \\
\hline NAP & $(0.05-0.8) /(0.1-0.4) / 0.06-0.6)$ & $(0.31 \pm 0.2) /(0.24 \pm 0.1) /(0.27 \pm 0.2)$ & $(0.48) /(0.39) /(0.25)$ \\
\hline $\mathrm{ACY}$ & $(0.01-1.2) /(0.1-0.8) /(0.1-1.2)$ & $(0.31 \pm 0.3) /(0.31 \pm 0.2) /(0.58 \pm 0.4)$ & $(0.35) /(0.46) /(0.50)$ \\
\hline $\mathrm{AC}$ & $(0.03-0.13) /(0.02-0.09) /(0.01-0.2)$ & $(0.07 \pm 0.02) /(0.04 \pm 0.03) /(0.07 \pm 0.07)$ & $(0.15) /(0.08) /(0.06)$ \\
\hline FLU & $(0.05-1.3) /(0.1-1.0) /(0.1-1.5)$ & $(0.43 \pm 0.3) /(0.41 \pm 0.3) /(0.63 \pm 0.4)$ & $(0.53) /(0.65) /(0.56)$ \\
\hline PHE & $(1.2-23.1) /(1.9-16.3) /(1.5-13.7)$ & $(7.38 \pm 5.5) /(6.30 \pm 5.3) /(8.4 \pm 4.0)$ & $(8.83) /(9.04) /(7.84)$ \\
\hline ANT & $(0.5-3.4) /(0.3-1.9) /(0.3-2.9)$ & $(1.07 \pm 0.7) /(0.79 \pm 0.6) /(1.43 \pm 0.8)$ & $(1.48) /(1.23) /(1.32)$ \\
\hline FLT & $(1.4-41.8) /(3.0-17.6) /(3.2-11.7)$ & $(12.9 \pm 10.0) /(9.10 \pm 5.7) /(8.97 \pm 2.7)$ & $(13.9) /(13.9) /(9.67)$ \\
\hline PYR & $(0.7-34.6) /(2.1-15.7) /(2.9-10.7)$ & $(9.85 \pm 8.2) /(7.48 \pm 5.0) /(8.1 \pm 2.5)$ & $(\mathbf{1 0 . 4}) /(11) /(8.69)$ \\
\hline $\mathbf{B a A}$ & $(1.3-27.7) /(1.3-17.5) /(2.1-18.8)$ & $(6.69 \pm 6.4) /(6.52 \pm 5.9) /(12 \pm 5.9)$ & $(7.17) /(8.23) /(11)$ \\
\hline CHR & $(1.4-37.5) /(2.1-20.8) /(2.7-15.9)$ & $(10.5 \pm 8.7) /(9.17 \pm 7.17) /(11.3 \pm 4.8)$ & $(11.2) /(12.4) /(10.8)$ \\
\hline $\mathbf{B b F}$ & $(1.5-35.3) /(2.1-21.3) /(2.3-20.4)$ & $(10.3 \pm 8.5) /(8.93 \pm 7.3) /(10.8 \pm 5.0)$ & $(11.2) /(11.8) /(10.4)$ \\
\hline $\mathrm{BkF}$ & $(1.6-15.4) /(1.2-7.4) /(1.3-6.6)$ & $(5.51 \pm 3.8) /(3.94 \pm 2.7) /(4.3 \pm 1.5)$ & $(6.76) /(5.80) /(4.43)$ \\
\hline BaP & $(1.4-37.3) /(1.5-20.7) /(3.2-35.2)$ & $(8.81 \pm 8.6) /(8.40 \pm 7.5) /(18.9 \pm 12.4)$ & $(9.12) /(10.3) /(16.1)$ \\
\hline IcdP & $(1.7-16.1) /(0.9-11.6) /(1.0-18.3)$ & $(4.79 \pm 3.5) /(4.65 \pm 4.3) /(9.75 \pm 6.4)$ & $(6.06) /(5.70) /(8.03)$ \\
\hline DahA & $(1.9-5.2) /(0.7-2.9) /(0.5-6.9)$ & $(2.54 \pm 0.7) /(1.46 \pm 0.8) /(3.0 \pm 2.1)$ & $(4.43) /(2.46) /(2.56)$ \\
\hline BghiP & $(2.53-17.0) /(1.2-10.7) /(1.4-15.4)$ & $(5.80 \pm 3.5) /(4.70 \pm 3.7) /(8.8 \pm 5.1)$ & $(7.86) /(6.47) /(7.62)$ \\
\hline Total & $(18-297) /(19-167) /(23-165)$ & $(87.3 \pm 58) /(72.5 \pm 56) /(107 \pm 51)$ & \\
\hline 10 OPAHs & $(3 \mathrm{~h}) /(9 \mathrm{~h}) /(15 \mathrm{~h})$ & $(3 \mathrm{~h} \pm \mathrm{SD}) /(9 \mathrm{~h} \pm \mathrm{SD}) /(15 \mathrm{~h} \pm \mathrm{SD})$ & $(3 \mathrm{~h}) /(9 \mathrm{~h}) /(15 \mathrm{~h})$ \\
\hline 1,4-NAQ & $(0.02-8.1) /(0.16-3.1) /(0.1-4.2)$ & $(2.25 \pm 2.4) /(1.27 \pm 1.2) /(1.66 \pm 1.3)$ & $(6.22) /(5.39) /(3.70)$ \\
\hline 1-NALD & $(0.2-0.8) /(0.07-0.5) /(0.08-0.9)$ & $(0.43 \pm 0.1) /(0.20 \pm 0.1) /(0.49 \pm 0.3)$ & $(2.71) /(1.19) /(1.25)$ \\
\hline 9-FLON & $(0.49-14.9) /(0.7-6.0) /(0.8-11.4)$ & $(6.76 \pm 4.4) /(2.56 \pm 1.9) /(4.26 \pm 2.8)$ & $(25.8) /(14.3) /(10.2)$ \\
\hline 9,10-ANQ & $(0.3-36.4) /(1.2-24.8) /(2.8-36)$ & $(8.31 \pm 8.8) /(8.65 \pm 8.5) /(14.3 \pm 9.9)$ & $(24.3) /(35.8) /(32.7)$ \\
\hline 1,8-NANYa & $(0.3-16.3) /(1.0-6.9) /(3.7-9.3)$ & $(7.09 \pm 5.4) /(3.69 \pm 2.9) /(6.81 \pm 2.8)$ & $(37.9) /(33.2) /(45.6)$ \\
\hline PHCA & $(0.1-0.9) /(0.05-0.6) /(0.06-1.9)$ & $(0.26 \pm 0.17) /(0.20 \pm 0.19) /(0.71 \pm 0.57)$ & $(1.42) /(0.99) /(1.50)$ \\
\hline BaFLU & $(0.06-10.8) /(0.1-8.1) /(0.4-15.1)$ & $(2.77 \pm 3.0) /(2.72 \pm 2.9) /(5.99 \pm 4.8)$ & $(7.47) /(9.73) /(12.1)$ \\
\hline BANTone & $(0.08-15.1) /(0.04-8.3) /(0.5-19.8)$ & $(2.46 \pm 3.3) /(2.63 \pm 2.9) /(9.27 \pm 7.3)$ & $(6.10) /(9.05) /(19.1)$ \\
\hline 1-PYRCA & $(0.007-1.8) /(0.008-1.5) /(0.05-2.4)$ & $(0.31 \pm 0.4) /(0.39 \pm 0.5) /(1.0 \pm 0.9)$ & $(0.74) /(1.24) /(1.96)$ \\
\hline 1,2-BANQ & $(0.02-3.6) /(0.03-2.6) /(0.2-3.9)$ & $(0.87 \pm 0.96) /(0.90 \pm 0.96) /(1.99 \pm 1.4)$ & $(2.3) /(3.24) /(4.33)$ \\
\hline Total & $(1.8-87.9) /(3.6-55.3) /(8.9-95.5)$ & $(28.7 \pm 21) /(21.7 \pm 18) /(41.6 \pm 26)$ & \\
\hline 9 NPAHs & $(3 \mathrm{~h}) /(9 \mathrm{~h}) /(15 \mathrm{~h})$ & $(3 \mathrm{~h} \pm \mathrm{SD}) /(9 \mathrm{~h} \pm \mathrm{SD}) /(15 \mathrm{~h} \pm \mathrm{SD})$ & $(3 \mathrm{~h}) /(9 \mathrm{~h}) /(15 \mathrm{~h})$ \\
\hline 1-NNAP & $(0.01-0.1) /(0.008-0.04) /(0.005-0.03)$ & $(0.03 \pm 0.02) /(0.01 \pm 0.01) /(0.01 \pm 0.008)$ & $(4.38) /(3.08) /(0.57)$ \\
\hline 3-NDBF & $(0.08-1.5) /(0.02-0.06) /(0.03-2.4)$ & $(0.33 \pm 0.31) /(0.03 \pm 0.01) /(0.89 \pm 0.84)$ & $(33.4) /(7.92) /(22.4)$ \\
\hline $5-\mathrm{NAC}{ }^{\mathrm{b}}$ & $(0.04-0.1) /(<\mathrm{LOQ}) /(0.03-0.35)$ & $(0.08 \pm 0.05) /(<\mathrm{LOQ}) /(0.18 \pm 0.13)$ & $(5.64) /(<\mathrm{LOQ}) /(4.67)$ \\
\hline 2-NFLU & $(0.03-0.3) /(0.01-0.3) /(0.01-0.5)$ & $(0.08 \pm 0.06) /(0.09 \pm 0.11) /(0.26 \pm 0.21)$ & $(10.15) /(10.00) /(7.28)$ \\
\hline 9-NANT & $(0.01-1.2) /(0.06-0.1) /(0.4-2.4)$ & $(0.36 \pm 0.37) /(0.41 \pm 0.31) /(1.18 \pm 0.6)$ & $(27.1) /(53.4) /(47.5)$ \\
\hline 3-NFLT & $(0.05-1.2) /(0.02-0.5) /(0.04-1.2)$ & $(0.34 \pm 0.3) /(0.21 \pm 0.2) /(0.54 \pm 0.4)$ & $(24.6) /(23.4) /(17.7)$ \\
\hline $1-N P Y R^{c}$ & $(0.01-0.1) /(0.01-0.06) /(0.008-0.2)$ & $(0.05 \pm 0.03) /(0.06 \pm 0.05) /(0.02 \pm 0.02)$ & $(2.92) /(2.48) /(2.01)$ \\
\hline 6-NCHR ${ }^{\mathrm{d}}$ & $(0.05-0.2) /(<\mathrm{LOQ}) /(0.009-0.02)$ & $(0.09 \pm 0.06) /(<\mathrm{LOQ}) /(0.01 \pm 0.007)$ & $(5.6) /(<\mathrm{LOQ}) /(0.5)$ \\
\hline $6-\mathrm{NBaP}^{\mathrm{e}}$ & $(<\mathrm{LOQ}) /(<\mathrm{LOQ}) /(0.02-0.08)$ & $(<\mathrm{LOQ}) /(<\mathrm{LOQ}) /(0.05 \pm 0.01)$ & $(<\mathrm{LOQ}) /(<\mathrm{LOQ}) /(1.26)$ \\
\hline Total & $(0.15-3.92) /(0.13-2.0) /(0.57-6.43)$ & $(1.17 \pm 1.0) /(0.80 \pm 0.66) /(3.06 \pm 1.8)$ & \\
\hline
\end{tabular}

${ }^{a}$ Quantified in 28/54 samples. ${ }^{\mathrm{b}}$ Quantified in 7/54 samples. ${ }^{\mathrm{c}}$ Quantified in 35/54 samples. ${ }^{\mathrm{d}}$ Quantified in 5/54 samples. ${ }^{\mathrm{e}}$ Quantified in 11/54 samples. * SD: standard deviation. 


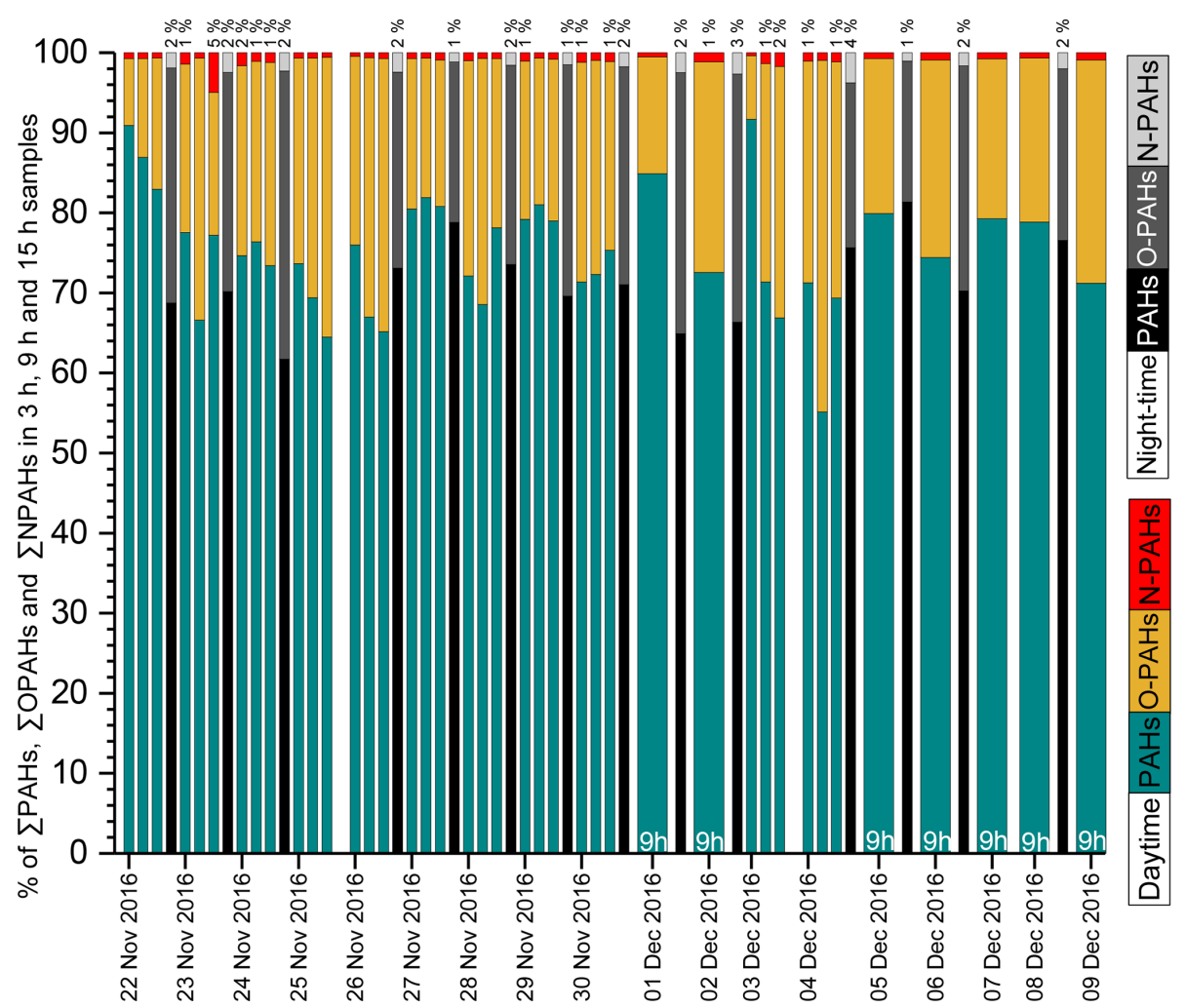

Figure 2. Time series of $\sum$ PAHs, $\sum$ OPAHs and $\sum$ NPAHs in PM $_{2.5}$ samples during the daytime ( 3 and $\left.9 \mathrm{~h}\right)$ and night-time (15 h). Percentages below $1 \%$ for NPAHs are omitted for clarity. Night-time data on 25 November 2016, 3 December 2016 and 7 December 2016 are not available due to a lack of samples.

monitoring studies are needed to confirm trends of NPAHs in China.

\subsection{Diagnostic ratios to identify emission sources}

The concentration ratios between different PAHs are widely used to assess and identify pollution emission sources (Tobiszewski and Namieśnik, 2012, and references therein). The ratios of FLT / (FLT + PYR) and IcdP / (IcdP + BghiP) isomer pairs are commonly used to distinguish between emission sources such as coal and biomass burning or the incomplete combustion of petroleum. Values of FLT / (FLT + PYR $)$ and IcdP / (IcdP + BghiP) higher than 0.5 indicate dominance of a coal or biomass burning source. Values of FLT / (FLT + PYR) between 0.4 and 0.5 and IcdP / (IcdP + BghiP) between 0.2 and 0.5 suggest a higher influence from fossil fuel combustion. Values of FLT / (FLT + PYR) less than 0.4 and IcdP / (IcdP + BghiP) less than 0.2 are mostly related to incomplete combustion (petrogenic origin) (Yunker et al., 2002; Pio et al., 2001). The measured ratios in this study are shown in Fig. 3 and ranged from 0.53 to 0.67 (mean 0.56) during the day ( 3 and $9 \mathrm{~h}$ samples), while at night ( $15 \mathrm{~h}$ samples) they varied between 0.51 and 0.54 (mean 0.52 ), indicating primary emissions from coal and biomass burning. Lower values were observed for IcdP / (IcdP + BghiP); daytime ratios were between 0.39 and 0.5 ( 3 and $9 \mathrm{~h}$ samples), indicating the dominance of petroleum combustion. At night, the ratio in most samples was slightly higher than 0.5 , with some values below, suggesting mixed sources with likely higher contributions coming from residential heating using coal and wood at night.

As shown in Fig. 4, other ratios can be useful to confirm the contribution from local traffic and to discriminate vehicle emissions such as $\mathrm{BaP} / \mathrm{BghiP}, \mathrm{FLU} / \mathrm{FLU}+\mathrm{PYR}$ and $\mathrm{BaP} / \mathrm{BaP}+\mathrm{CHR}$ (Tobiszewski and Namieśnik, 2012, and references therein). The $\mathrm{BaP} / \mathrm{BghiP}$ ratios were significantly higher than 0.6 , indicating a major influence from road traffic, while FLU / FLU + PYR ratios suggested a predominant petrol contribution (ratio $<0.5$ ) instead of diesel engines (ratio >0.5). Results shown in Fig. 4 identify traffic emissions and in particular petrol engines as the major emitter of PAHs. In $\mathrm{PM}_{2.5}$, the five- and six-ring PAH species (BaP, IcdP, BghiP) were previously attributed to petrol engines, while lower-molecular-weight species with three rings (ACY, AC, FLU, PHE, ANT) and four rings (FLT, PYR, BaA, CHR) were closely related to diesel vehicle emissions (Chiang et al., 2012; Wu et al., 2014, and references therein). Previous studies in Beijing and Guangzhou in China suggested similar contributions from coal and petroleum combustion, focusing 


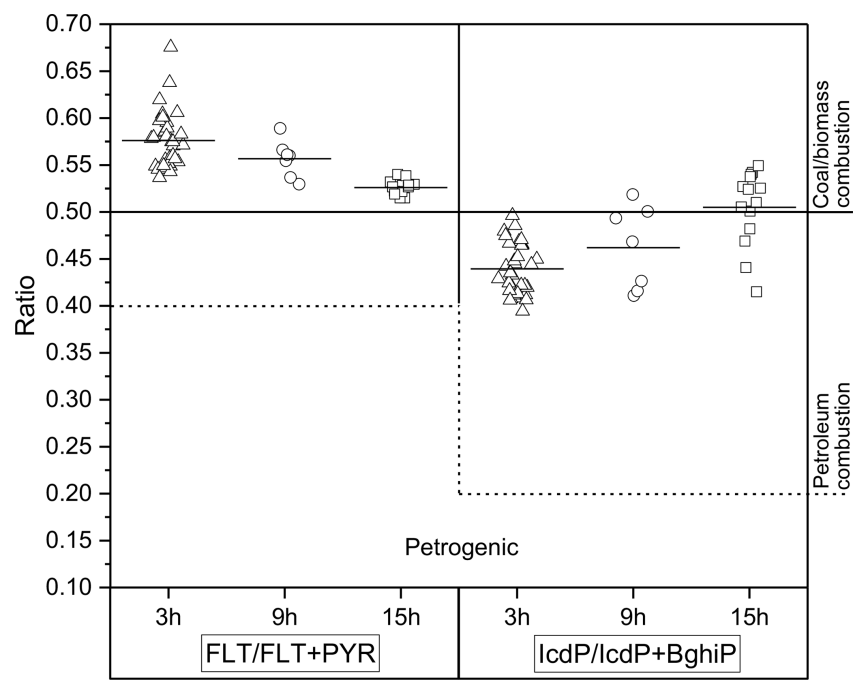

Figure 3. Column scatter of FLT / FLT + PYR) and IcdP / (IcdP + BghiP $)$ in the particulate phase for three different time sampling averages. Open triangles and circles represent the daytime data for 3 and $9 \mathrm{~h}$ samples, and open squares represent the night-time data of $15 \mathrm{~h}$. The dashed line separates the petroleum combustion source from the petrogenic source for both ratios. The solid short line on each data set represents the mean value of ratios.

on vehicular traffic (petrol and diesel) as potential sources of PAHs (Gao and Ji, 2018; Liu et al., 2015; Wu et al., 2014, Niu et al., 2017).

NPAHs can be used to track the photochemistry of PAHs with $\mathrm{OH}$ and $\mathrm{NO}_{3}$ radicals, both of which can generate secondary photochemical products of NPAHs and OPAHs from primary PAH emissions (Zhang et al., 2018; Ringuet et al., 2012b; Wang et al., 2011a). 1-NPYR originates mainly from primary emissions and in particular from diesel vehicles (Keyte et al., 2016; Schulte et al., 2015), whilst 2-NFLT has been reported to be absent in direct combustion emissions, instead produced from the gas-phase reactions of FLT with $\mathrm{OH}$ radicals in the presence of $\mathrm{NO}_{x}$ during the day or $\mathrm{NO}_{3}$ radicals at night. 2-NPYR comes solely from the reaction of PYR with OH radicals (Ramdahl et al., 1986; Arey et al., 1986; Atkinson et al., 1987; Ciccioli et al., 1996). Accordingly, the ratio 2-NFLT / 1-NPYR has been widely used as diagnostic, with a value greater than 5 indicating a major contribution from photochemical processes, whilst a ratio value less than 5 means an important contribution from direct emissions (Albinet et al., 2008; Wang et al., 2011a; Ringuet et al., 2012b; Bandowe et al., 2014; Tomaz et al., 2017; Zhang et al., 2018).

In this study, the 2-NFLT was not quantified because the standard compound was not commercially available; subsequently, we used the 3-NFLT isomer as a substitution for 2-NFLT. PAH isomer pairs (Table 1) in standard mixtures showed similar sensitivities for each concentration used, therefore, we assume an equal sensitivity for 2-NFLT and

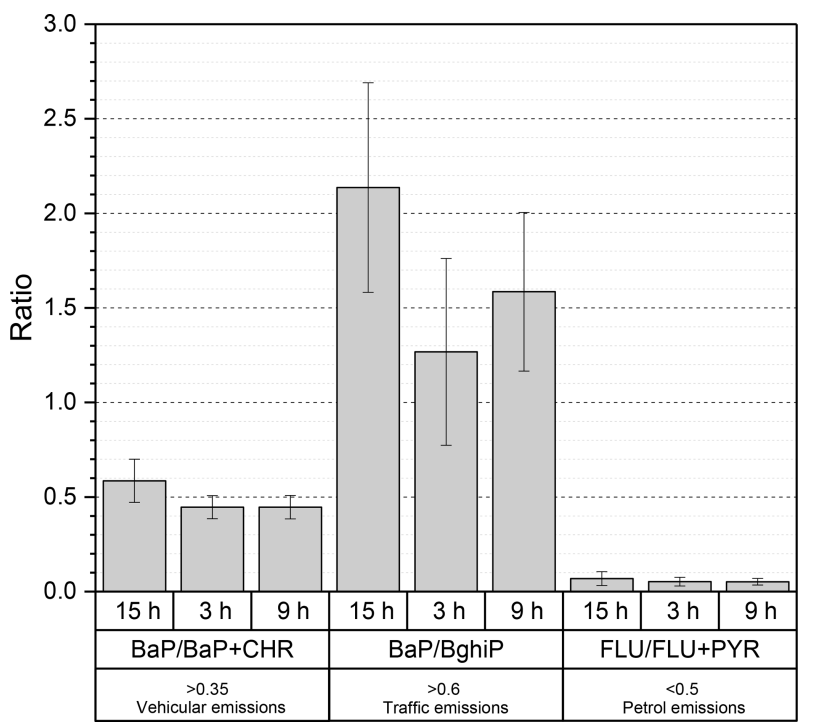

Figure 4. Column distribution of $\mathrm{BaP} / \mathrm{BaP}+\mathrm{CHR}$, $\mathrm{BaP} / \mathrm{BghiP}$ and FLU / FLU + PYR in the particulate phase for three different sampling periods. 3 and $9 \mathrm{~h}$ represent samples collected during the day, and $15 \mathrm{~h}$ represents samples at night. Error bars reflect standard deviations.

3-NFLT during analysis. A previous study reported that the concentration of 3-NFLT compared to 2-NFLT is relatively very low in ambient air (Bamford et al., 2003); in addition, the separation of both isomers (2- and 3-NFLT) using the most common GC-MS column for PAH separation, HP-5ms and DB-5ms, was not possible (Zhang et al., 2018; Bandowe et al., 2014; Ringuet et al., 2012b; Albinet et al., 2008). Hence, we assume that the sum of 2- and 3-NFLT is closely representative of the original ratio 2-NFLT / 1-NPYR. Therefore, we adopted the ratio $2+3$ NFLT / 1-NPYR, which varied between 4 and 19 during the daytime (mean: 12) and from 3.6 to 30.4 in the night-time (mean: 8.8) (Fig. S3). Most daytime values exceeded the benchmark ratio of 5 significantly, while at night-time the average value was lower. These results indicate the predominance of $\mathrm{OH}$-radical-initiated reactions controlling the formation of 2-NFLT in the presence of $\mathrm{NO}_{2}$ and sunlight.

\subsection{Correlation with gaseous pollutants}

$\mathrm{O}_{3}, \mathrm{CO}, \mathrm{NO}, \mathrm{NO}_{2}, \mathrm{SO}_{2}$ and $\mathrm{HONO}$ were also measured at the same site location as the $\mathrm{PM}_{2.5}$ sampling. Inlets were installed outside lab containers approximately $3-4 \mathrm{~m}$ above ground (Fig. S1). Online measurements of the gas-phase species have been time-averaged to the filter sampling times. No correlations of significance were seen between PAHs and meteorological parameters (relative humidity and temperature), as shown in Table S1 in the Supplement.

$\sum$ PAHs and $\sum$ OPAHs had a similar strong positive correlation $(R=0.82$ to 0.98$)$ in the 9 and $15 \mathrm{~h}$ samples with $\mathrm{CO}, \mathrm{NO}, \mathrm{NO}_{2}, \mathrm{SO}_{2}$ and $\mathrm{HONO}$ (Table $\mathrm{S} 1$ ). $\mathrm{NO}$ is known 

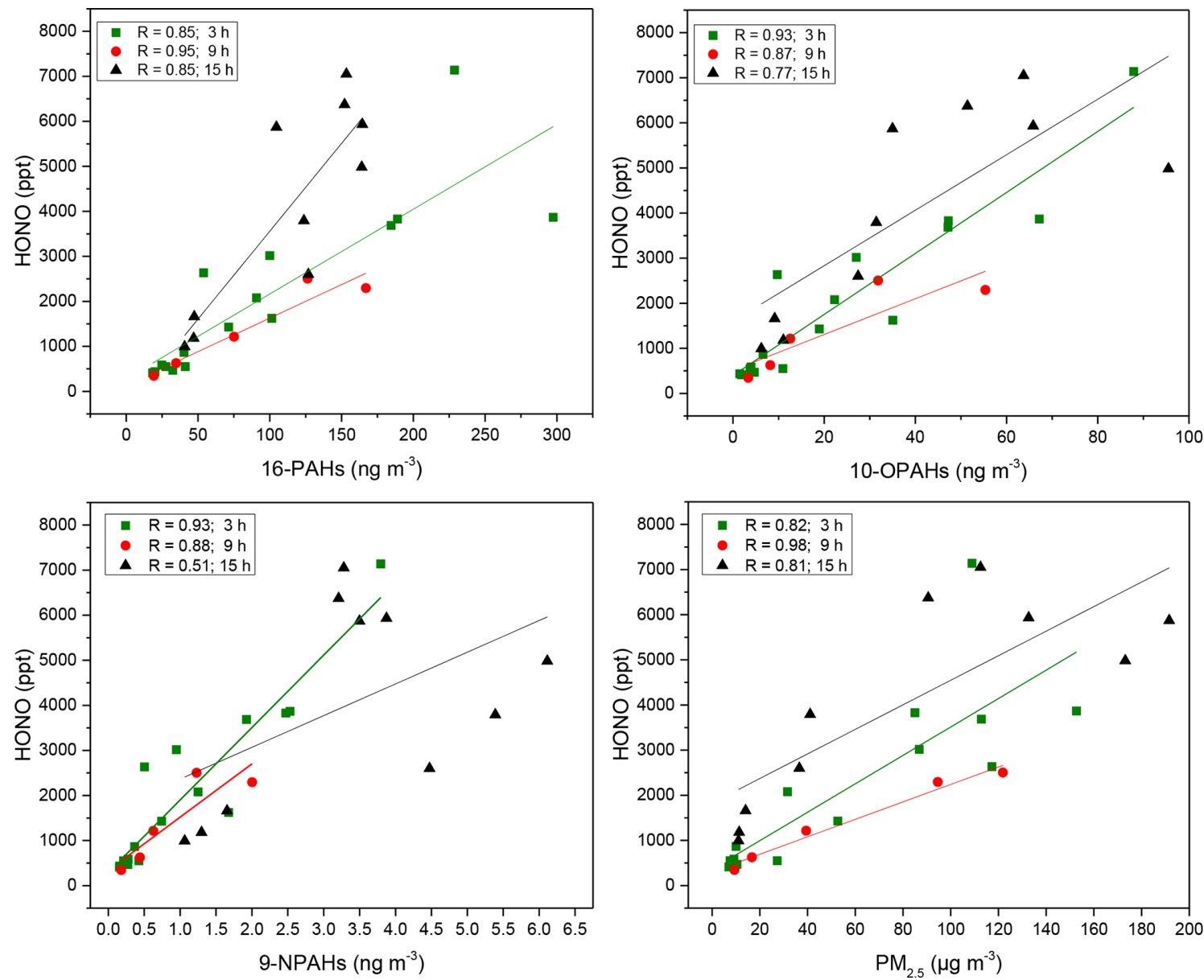

Figure 5. Correlation coefficients of $\sum$ PAHs, $\sum$ OPAHs, $\sum$ NPAHs and $\mathrm{PM}_{2.5}$ with HONO. The time sampling resolution of 3 and $9 \mathrm{~h}$ refers to daytime concentrations and $15 \mathrm{~h}$ to nocturnal concentrations. Significance levels were between 0.001 and 0.05 except for HONO and NPAHs at night for which the $P$ level $>0.05$, and the Pearson coefficient was 0.52 .

as an effective tracer for local traffic emissions, and it behaves as a short-lived intermediate (Bange, 2008; Janhäll et al., 2004). CO is mainly produced from incomplete combustion and has a relatively long atmospheric lifetime (3 months on average) and undergoes long-range transport (Peng et al., 2007, and references therein). The high correlations with primary pollutants such as $\mathrm{NO}$ and $\mathrm{CO}$ during the daytime and night-time indicate that PAHs and OPAHs are primarily emitted from local sources, which may also be associated with regional scale emissions. Significant correlations were observed with $\mathrm{SO}_{2}$, a pollutant mostly emitted from power plants outside the city (Lee et al., 2011). This strong relationship with $\mathrm{SO}_{2}$ could be explained by the contribution of anthropogenic sources such as the Beijing Taiyanggong thermal power station $\left(39^{\circ} 58^{\prime} 42 \mathrm{~N}, 116^{\circ} 26^{\prime} 19 \mathrm{E}\right)$ and is consistent with the domain air masses arriving at the sites from the north-east for much of the time (Fig. S4).

In contrast, most of the $3 \mathrm{~h}$ day samples showed only moderate correlations $(R=0.38$ to 0.74$)$ except for HONO for which significant correlations $(R=0.87$ to 0.94$)$ were ob- served with $\sum$ PAHs, $\sum$ OPAHs and $\sum$ NPAHs (Fig. 5; Table S1). Furthermore, HONO was significantly correlated with $\mathrm{PM}_{2.5}$ during the daytime (Fig. 5), and some significant chemical link between HONO emissions and ambient particles $\left(\mathrm{PM}_{2.5}\right)$ is implied. A similar conclusion was drawn from a recent study in Beijing (Zhang et al., 2019) which suggested a potential chemical relationship between HONO and haze particles $\left(\mathrm{PM}_{2.5}\right)$ and proposed a high contribution from vehicle emissions to the night-time HONO.

For NPAHs, as shown in Table S1, no significant correlation was found in 3 and $15 \mathrm{~h}$ time sampling resolution, except with HONO, for which a significant difference between day and night was observed. Surprisingly, the $9 \mathrm{~h}$ time resolution showed a strong correlation with $\mathrm{CO}, \mathrm{NO}, \mathrm{NO}_{2}$ and $\mathrm{SO}_{2}$, potentially suggesting direct emission of NPAHs. More likely these correlations arise because of a formation delay of NPAHs that is smoothed out by the longer daytime sampling period. In a previous study, Zimmermann et al. (2013) reported the formation of NPAHs from the heterogeneous interaction of ambient particle-bound PAHs with 


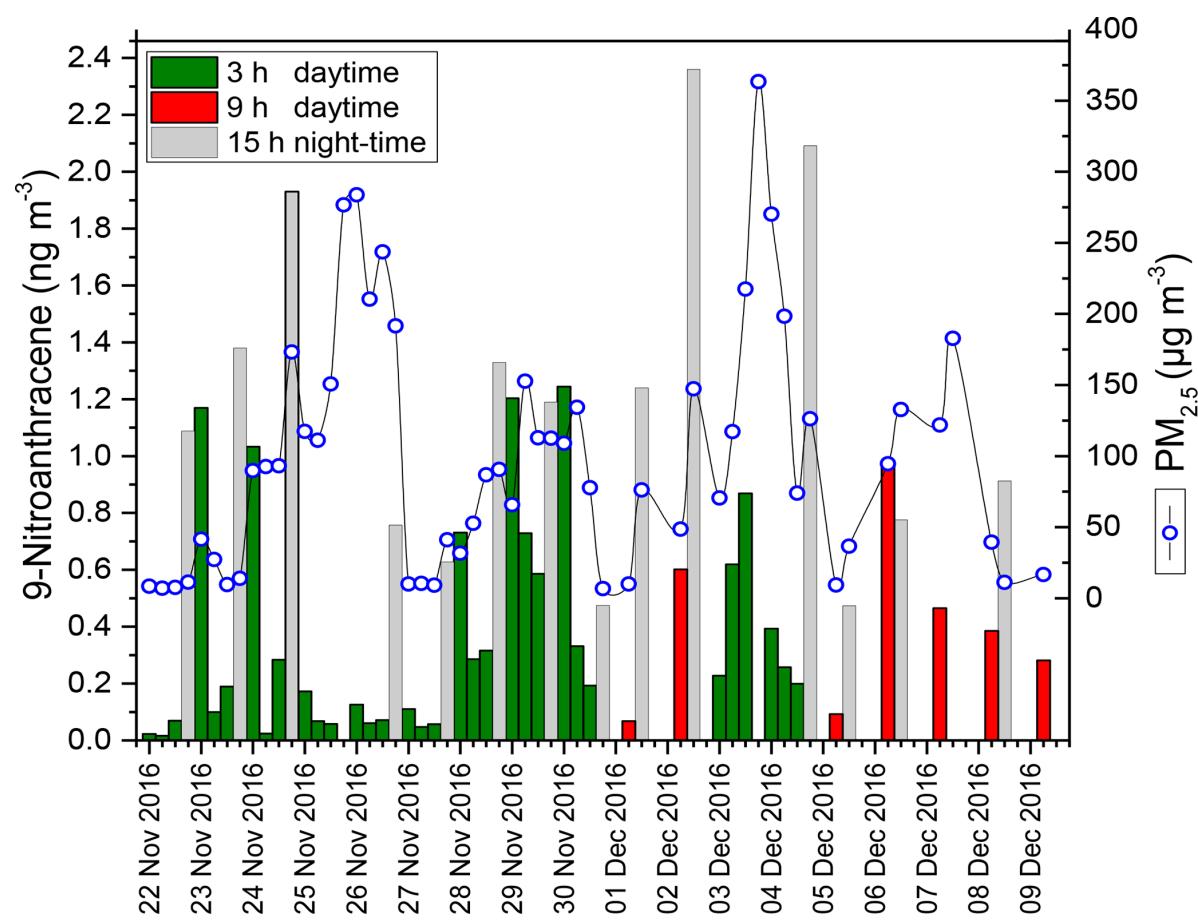

Figure 6. Temporal variation of 9-nitroanthracene and $\mathrm{PM}_{2.5}$ over the entire winter campaign.

atmospheric oxidants. In line with the observed high values for the ratio $2+3 \mathrm{NFLT} / 1$-NPYR (Sect. 3.2) and the trace levels of NPAH concentrations in the atmosphere, the secondary formation of NPAHs by gas-phase reactions followed by adsorption on particles and in parallel the heterogeneous formation on the surface of particles is supported rather than primary emissions.

HONO plays a key role in tropospheric photochemistry; however its sources and their relative contributions to ambient HONO are still unclear, especially in the daytime. To help understand the mechanism of HONO formation in the atmosphere, each NPAH compound has been correlated with HONO concentrations. The available data in Table S2 show diurnal and nocturnal differences for individual correlations of NPAHs with HONO with the exception of 1-NPYR, which originates mainly from primary emissions and shows a strong correlation during the day and night. 9-Nitroanthracene showed distinctive behaviour, accumulating during the night and appearing to undergo a photodegradation during the daytime (Fig. 6). As shown in Table S2, 9-nitroanthracene showed a strong positive correlation with HONO $(R=0.90, P<0.001)$ in the daytime, while no significant relationship was found at night-time $(R=0.15, P>0.05)$. This suggests 9-nitroanthracene as a possible source of HONO during the daytime via the $\mathrm{OH}$ radical-initiated reaction leading to $\mathrm{OH}$ (ortho) addition and followed by intramolecular hydrogen transfer from the phenolic hydroxyl group to the nitro group.
There was a significant positive correlation between ANT and 9-NANT ( $R=0.90,3 \mathrm{~h} ; R=0.94,9 \mathrm{~h} ; R=0.90,15 \mathrm{~h}$; $P \leq 0.001$ ), which may be an indication that 9-NANT is closely related to ANT. In this respect, additional simulation chamber measurements of the gas-phase reaction of ANT with $\mathrm{NO}_{3}$ radicals and for 9-nitroanthracene with $\mathrm{OH}$ radicals in the presence of light and under different atmospheric parameters are required for more precise assessment.

\subsection{Exposure assessment}

The toxicity equivalency factor (TEF) represents an estimate of the relative toxicity of a chemical compared to a reference chemical. For PAHs, benzo[a]pyrene was chosen as the reference chemical because it is known as the most carcinogenic PAH (OEHHA, 1994, 2002) and is commonly used (Albinet et al., 2008; Tomaz et al., 2016; Alves et al., 2017; Bandowe et al., 2014; Ramírez et al., 2011) as an indicator of carcinogenicity of total PAHs. The toxicity of the total PAHs expressed as $\mathrm{BaP}$ equivalents $\left(\mathrm{BaP}_{\mathrm{eq}}\right)$ is calculated from the TEFs of each target compound (Table S3) multiplied by its corresponding concentration:

$\sum[\mathrm{BaP}]_{\mathrm{eq}}=\sum_{i}^{n=1}\left(C_{\mathrm{i}} x \mathrm{TEF}_{i}\right)$

where $C_{\mathrm{i}}$ corresponds to the concentration of individual target compounds (PAHs, OPAHs and NPAHs) in nanograms per cubic metre $\left(\mathrm{ng} \mathrm{m}^{-3}\right)$. 
Table 3. Average concentration of $\sum \mathrm{BaP}_{\mathrm{eq}}$ in nanograms per cubic metre $\left(\mathrm{ng} \mathrm{m}^{-3}\right)$ and cancer risk assessment for the sum of $16 \mathrm{PAHs}$, $1 \mathrm{OPAH}$ and 6 NPAHs.

\begin{tabular}{lcccc}
\hline Sampling hours & $\begin{array}{c}\sum[\mathrm{BaP}]_{\mathrm{eq}} \\
\mathrm{ng} \mathrm{m}^{-3}\end{array}$ & $\begin{array}{c}\mathrm{UR}_{\mathrm{BaP}}=1.1 \times 10^{-6} \\
(\mathrm{CalEPA})\end{array}$ & $\begin{array}{c}\mathrm{UR}_{\mathrm{BaP}}=8.7 \times 10^{-5} \\
(\text { WHO })\end{array}$ & $\begin{array}{c}\text { Risk per } \\
\text { million people }\end{array}$ \\
\hline $9 \mathrm{~h}(\text { daytime, } n=40)^{\mathrm{a}}$ & $15.9^{\mathrm{a}}$ & $1.75 \times 10^{-5}$ & $1.38 \times 10^{-3}$ & $17^{\mathrm{b}}-1383^{\mathrm{c}}$ \\
$15 \mathrm{~h}($ night-time,$n=14)$ & 28.3 & $3.17 \times 10^{-5}$ & $2.46 \times 10^{-3}$ & $31^{\mathrm{b}}-2460^{\mathrm{c}}$ \\
$24 \mathrm{~h}(n=54)$ & 23.6 & $2.6 \times 10^{-5}$ & $2.05 \times 10^{-3}$ & $26^{\mathrm{b}-2053^{\mathrm{c}}}$ \\
\hline
\end{tabular}

${ }^{\mathrm{a}}$ Average includes combined $3 \mathrm{~h}$ samples in each day $(n=33)$ and $9 \mathrm{~h}$ samples $(n=7) .{ }^{\mathrm{b}}$ Calculated value according to CalEPA.

${ }^{c}$ Calculated value according to WHO. $n$ : number of samples.

A widely applied procedure from the Office of Environmental Health Hazards Assessment (OEHHA) of the California Environmental Protection Agency (CalEPA) and also the World Health Organization (WHO) was used here to evaluate and calculate the potential of contracting cancer from inhalation and exposure to $\mathrm{PM}_{2.5}$-bound PAHs, commonly known as the lifetime excess cancer risk (ECR):

$\mathrm{ECR}=\sum[\mathrm{BaP}]_{\mathrm{eq}} \times \mathrm{UR}_{\mathrm{BaP}}$,

where two values are mostly used for the unit risk (UR), i.e. $\mathrm{UR}_{[\mathrm{BaP}]}\left(1.1 \times 10^{-6}\left(\mathrm{ng} \mathrm{m}^{-3}\right)^{-1}\right.$ (OEHHA, 2002, 2005) and $8.7 \times 10^{-5}\left(\mathrm{ng} \mathrm{m}^{-3}\right)^{-1}$, WHO, 2000). Equation (2) describes the inhalation unit risk associated with a high probability of contracting cancer when exposed continuously to $1 \mathrm{ng} \mathrm{m}^{-3}$ of $\mathrm{BaP}_{\mathrm{eq}}$ concentration over a lifetime of 70 years.

As shown in Table 3, the $\mathrm{BaP}_{\text {eq }}$ concentration includes the sum of 16 PAHs, 1 OPAH and 6 NPAHs, with the cancer risk evaluated using different sampling times according to CalEPA and WHO guidelines. The risk values may be underestimated due to a lack of toxicity data for OPAHs and because our assessment excludes the gas-phase contributions; i.e. they are only based on the health risk evaluation of the particulate phase. The average $24 \mathrm{~h} \mathrm{BaP}$ eq for the whole sampling period was $23.6 \pm 12.4 \mathrm{ng} \mathrm{m}^{-3}$ (Table 3). As shown in Table 2, 6-NCHR has not been quantified in all samples; its contribution to the total $\mathrm{BaP}_{\text {eq }}$ is relatively high (mean: $8 \%$, range: $1 \%-24 \%$ ) in comparison with the three major contributors from the PAH group: $\mathrm{BaP}$ (mean: $47.5 \%$, range: $24 \%-64 \%$ ), DahA (mean: $17.8 \%$, range: $10 \%-32 \%$ ) and $\mathrm{BbF}$ (mean: $10.1 \%$, range: $7 \%-21 \%$ ). In this study, the ECR attributable to all polycyclic aromatic compounds (PACs) in urban air of Beijing ranged from $10^{-5}$ to $10^{-3}>10^{-6}$ (Table 3), suggesting an elevated potential cancer risk for adults (Chen and Liao, 2006; Bai et al., 2009).

It is worth noting that inhalation exposure is not the only risk related to PAHs and cancer in humans. Other sources of exposure include dermal contact and ingestion of the resuspended dusts in matrices such as road dusts and soils, all of which increase the risk value for urban residents (Wang et al., 2011b; Wei et al., 2015). In this study, the $24 \mathrm{~h}$ average estimated cancer risk (Table 3) from inhalation exposure to ambient $\mathrm{PM}_{2.5}$ based on CalEPA and WHO guidelines was
$2.6 \times 10^{-5}$ and $2.05 \times 10^{-3}$, respectively. Using the highest calculated ECR $\left(2.05 \times 10^{-3}\right)$ gives an estimate of $2027 \mathrm{ad}-$ ditional cancer cases per million people exposed (29 cases per year) in comparison to the estimate based on CalEPA of 26 persons ( 0.37 cases per year).

ECR trends were reported in previous studies from Beijing and other populated area (Bandowe et al., 2014; Alves et al., 2017; Ramírez et al., 2011; Jia et al., 2011; Liu et al., 2015; Song et al., 2018; Feng et al., 2019). In this study we considered the combination of all samples $(n=54)$ to estimate the average $24 \mathrm{~h}$ cancer risk $\left(\sum[\mathrm{BaP}]_{\mathrm{eq}}=23.6 \pm 12 \mathrm{ng} \mathrm{m}^{-3}\right.$; range $8-44 \mathrm{ng} \mathrm{m}^{-3}$ ) and compare it with previous studies. An average value of $17 \mathrm{ng} \mathrm{m}^{-3}$ (range 2-64 $\mathrm{ng} \mathrm{m}^{-3}$ ) was reported for Xi' an for the whole year between July 2008 and August 2009 (Bandowe et al., 2014). After considering the same winter period (November and December) as in our study, the average values reported for Xi' an (31-33 $\mathrm{ng} \mathrm{m}^{-3}$ ) were higher than our results. In contrast, our average value was comparable to those reported in a recent study in Beijing, ranging from 21 to $38 \mathrm{ng} \mathrm{m}^{-3}$ in cold months (Feng et al., 2019), whilst in the previous study of Chen et al. (2017), they reported an average of $31.4 \mathrm{ng} \mathrm{m}^{-3}$ for outdoor air in Beijing in winter. Lower and more varied values have been also reported in Beijing in winter. Liu et al. (2007) reported an average $\mathrm{BaP}_{\mathrm{eq}}$ concentration of 13.0 and $27.3 \mathrm{ng} \mathrm{m}^{-3}$ at two sampling sites at Peking University campus and $82.1 \mathrm{ng} \mathrm{m}^{-3}$ for samples collected from a busy road. It is clear that direct comparison with Beijing air from other studies is limited due to the variable number of compounds considered in each study and the differences in sampling sites and sampling periods. Other areas of uncertainty include TEF reference values and the range of $\mathrm{BaP}$ UR, which were extrapolated from animal bioassays with limited evidence regarding the carcinogenicity to humans.

Seasonal variability is also crucial in estimating $\mathrm{BaP}_{\mathrm{eq}}$ concentrations; it has been shown that $\mathrm{BaP}_{\mathrm{eq}}$ values in cold months are always higher than warm months due to the increase in coal combustion, central and residential heating, lower photochemical transformation and lower volatilization of gases favouring particle formation in winter. Previous observations in Beijing recorded $\sum\left[\mathrm{BaP}_{\mathrm{eq}}\right]$ of $11.1 \mathrm{ng} \mathrm{m}^{-3}$ in autumn (Jia et al., 2011) and $11.0 \mathrm{ng} \mathrm{m}^{-3}$ in warm months 
(April to June) (Feng et al., 2019). In comparison with Guangzhou (south of China), $\mathrm{BaP}_{\mathrm{eq}}$ was $9.24 \mathrm{ng} \mathrm{m}^{-3}$ in winter and reported to be 1.6 and 6.2 times greater than autumn and summer, respectively (Liu et al., 2015). Our results were considerably higher than those estimated for western European cities during the winter, such as $1.4 \mathrm{ng} \mathrm{m}^{-3}$ in Grenoble (Tomaz et al., 2016), $3.56 \mathrm{ng} \mathrm{m}^{-3}$ in Oporto, $1.39 \mathrm{ng} \mathrm{m}^{-3}$ in Florence and $0.43 \mathrm{ng} \mathrm{m}^{-3}$ in Athens (Alves et al., 2017). ECR values estimated for each city were 31 (Grenoble), 6.6 (Oporto), 17 (Florence) and 54 (Athens) times lower than our ECR estimation. Lower ECR levels in western European cities were attributed to cleaner energy sources, less densely populated cities, waste export and recycling and more effective environmental regulations.

\section{Conclusions}

Temporal variations and chemical composition of $\mathrm{PM}_{2.5}$ were measured in Beijing, China, from 22 November to 9 December 2016, focusing in particular on the diurnal and nocturnal chemical formation of PAHs, OPAHs and NPAHs. The $24 \mathrm{~h}$ average concentration of $\mathrm{PM}_{2.5}$ was $108 \mu \mathrm{g} \mathrm{m}^{-3}$, ranging from 10 to $283 \mu \mathrm{g} \mathrm{m}^{-3}$, exceeding the $24 \mathrm{~h}$ limit value for China on 10 out of 18 sampling days. The $24 \mathrm{~h}$ concentrations of $\sum \mathrm{PAH}_{16}$ varied between 37 and $180 \mathrm{ng} \mathrm{m}^{-3}$ (average $97 \pm 43 \mathrm{ng} \mathrm{m}^{-3}$ ), while $\sum \mathrm{OPAH}_{10}$ ranged from 13 to $70 \mathrm{ng} \mathrm{m}^{-3}$ (average $35.6 \pm 19 \mathrm{ng} \mathrm{m}^{-3}$ ) and $\sum \mathrm{NPAH}_{9}$ from 0.87 to $4.4 \mathrm{ng} \mathrm{m}^{-3}$ (average $2.29 \pm 1.2 \mathrm{ng} \mathrm{m}^{-3}$ ). Daytime concentrations during pollution episodes for PAHs, OPAHs and NPAHs were 224,54 , and $2.3 \mathrm{ng} \mathrm{m}^{-3}$, respectively. The daily concentration of benzo[a]pyrene exceeded the $24 \mathrm{~h}$ average limit value of $2.5 \mathrm{ng} \mathrm{m}^{-3}$ for China on all sampling days in this study, indicating elevated risk of disease among inhabitants.

Diagnostic ratios of different species were used to distinguish between possible emission sources of PAHs. Coal combustion and road traffic emissions (petrol engines) were found overall to be the two dominant sources. In addition, high ratios of 2+3-nitrofluoranthene / 1-nitropyrene indicated significant secondary formation of NPAHs, especially in daytime via the $\mathrm{OH}$-radical-initiated reaction pathway.

PAH and OPAH concentrations were correlated with $\mathrm{CO}$, $\mathrm{NO}, \mathrm{NO}_{2}, \mathrm{SO}_{2}$ and $\mathrm{HONO}$, indicating that both are associated with local and regional primary emissions and in particular to traffic sources. Correlations seen previously between $\mathrm{PM}_{2.5}$ and HONO suggested a possible link and a potential source of HONO that would affect the budget of HONO and $\mathrm{OH}$ radicals. The strong positive correlation between individual NPAHs and HONO during daytime was also suggestive of a potential link between these two classes of chemicals in air. One of the dominant NPAHs, 9-nitroanthracene, showed distinctive behaviour, accumulating at night and photodegrading in daytime.
The lifetime excess cancer risk attributable to the summation of polycyclic aromatic compounds measured here and associated with $\mathrm{PM}_{2.5}$ inhalation in Beijing was in the range of $10^{-3}$ according to WHO guidelines, confirming that there is a statistically elevated risk of contracting cancer from this class of pollutants in this location.

Data availability. Variability of all compounds is presented in Table 2 and throughout the different sections of the paper. Specific data requests can be addressed by email to the corresponding authors.

Supplement. The supplement related to this article is available online at: https://doi.org/10.5194/acp-19-8741-2019-supplement.

Author contributions. AE led the analysis and prepared the manuscript with contributions from all authors. ACL and JFH contributed to the analysis, interpretation and writing of the paper. RED provided the data on the gas-phase measurements and collected the filter samples in the field. MWW supported laboratory chemical analysis on the GC-Q-ToF-MS. All authors contributed to the corrections of the paper.

Competing interests. The authors declare that they have no competing interests.

Special issue statement. This article is part of the special issue "In-depth study of air pollution sources and processes within Beijing and its surrounding region (APHH-Beijing) (ACP/AMT interjournal SI)". It is not associated with a conference.

Acknowledgements. Authors gratefully acknowledge the UK Natural Environment Research Council for funding the Air Pollution and Human Health programme, reference NE/N007115/1 and NE/N006917/1. We thank Leigh Crilley and Louisa Kramer from the University of Birmingham for provision of HONO data, funded through the APHH AIRPRO and AIRPOLL projects, reference NE/N007115/1 and NE/N006917/1. Authors gratefully acknowledge the vital contributions of Pingqing $\mathrm{Fu}$ and his staff at the Institute of Atmospheric Physics, CAS, in Beijing for enabling the field observations and providing resources to support the wider project.

Financial support. This research has been supported by the Natural Environment Research Council (grant nos. NE/N007115/1 and NE/N006917/1).

Review statement. This paper was edited by Delphine Farmer and reviewed by two anonymous referees. 


\section{References}

Abbas, I., Badran, G., Verdin, A., Ledoux, F., Roumie, M., and Courcot, D.: Polycyclic aromatic hydrocarbon derivatives in airborne particulate matter: sources, analysis and toxicity, Environ. Chem. Lett., 16, 439-475, https://doi.org/10.1007/s10311-0170697-0, 2018.

Albinet, A., Leoz-Garziandia, E., Budzinski, H., and Villenave, E.: Simultaneous analysis of oxygenated and nitrated polycyclic aromatic hydrocarbons on standard reference material 1649a (urban dust) and on natural ambient air samples by gas chromatography-mass spectrometry with negative ion chemical ionisation, J. Chromatogr. A, 1121, 106-113, https://doi.org/10.1016/j.chroma.2006.04.043, 2006.

Albinet, A., Leoz-Garziandia, E., Budzinski, H., and Villenave, E.: Polycyclic aromatic hydrocarbons (PAHs), nitrated PAHs and oxygenated PAHs in ambient air of the Marseilles area (South of France): Concentrations and sources, Sci. Total Environ., 384, 280-292, https://doi.org/10.1016/j.scitotenv.2007.04.028, 2007a.

Albinet, A., Leoz-Garziandia, E., Budzinski, H., and Villenave, E.: Sampling precautions for the measurement of nitrated polycyclic aromatic hydrocarbons in ambient air, Atmos. Environ., 41, 4988-4994, https://doi.org/10.1016/j.atmosenv.2007.01.061, 2007b.

Albinet, A., Leoz-Garziandia, E., Budzinski, H., Villenave, E., and Jaffrezo, J. L.: Nitrated and oxygenated derivatives of polycyclic aromatic hydrocarbons in the ambient air of two French alpine valleys Part 1: Concentrations, sources and gas/particle partitioning, Atmos. Environ. 42, 43-54, https://doi.org/10.1016/j.atmosenv.2007.10.009, 2008.

Albinet, A., Papaiconomou, N., Estager, J., Suptil, J., and Besombes, J.-L.: A new ozone denuder for aerosol sampling based on an ionic liquid coating, Anal. Bioanal. Chem., 396, 857-864, https://doi.org/10.1007/s00216-009-3243-5, 2009.

Albinet, A., Nalin, F., Tomaz, S., Beaumont, J., and Lestremau, F.: A simple QuEChERS-like extraction approach for molecular chemical characterization of organic aerosols: application to nitrated and oxygenated PAH derivatives (NPAH and OPAH) quantified by GC-NICIMS, Anal. Bioanal. Chem., 406, 3131-3148, https://doi.org/10.1007/s00216-014-7760-5, 2014.

Alves, C. A., Vicente, A. M., Custódio, D., Cerqueira, M., Nunes, T., Pio, C., Lucarelli, F., Calzolai, G., Nava, S., Diapouli, E., Eleftheriadis, K., Querol, X., and Musa Bandowe, B. A.: Polycyclic aromatic hydrocarbons and their derivatives (nitro-PAHs, oxygenated PAHs, and azaarenes) in $\mathrm{PM}_{2.5}$ from Southern European cities, Sci. Total Environ., 595, 494-504, https://doi.org/10.1016/j.scitotenv.2017.03.256, 2017.

Andreou, G. and Rapsomanikis, S.: Polycyclic aromatic hydrocarbons and their oxygenated derivatives in the urban atmosphere of Athens, J. Hazard. Mater., 172, 363-373, https://doi.org/10.1016/j.jhazmat.2009.07.023, 2009.

Arey, J., Zielinska, B., Atkinson, R., Winer, A. M., Ramdahl, T., and Pitts, J. N.: The formation of nitro-PAH from the gasphase reactions of fluoranthene and pyrene with the $\mathrm{OH}$ radical in the presence of $\mathrm{NO}_{x}$, Atmos. Environ., 20, 2339-2345, https://doi.org/10.1016/0004-6981(86)90064-8, 1986.

Arey, J., Zielinska, B., Atkinson, R., and Winer, A. M.: Formation of nitroarenes during ambient high-volume sampling, Env. Sci. Tech., 22, 457-462, https://doi.org/10.1021/es00169a015, 1988.
Atkinson, R., Arey, J., Zielinska, B., Pitts, J. N., and Winer, A. M.: Evidence for the transformation of polycyclic organic matter in the atmosphere, Atmos. Environ., 21, 2261-2262, https://doi.org/10.1016/0004-6981(87)90357-X, 1987.

Atkinson, R., Arey, J., Zielinska, B., and Aschmann, S. M.: Kinetics and nitro-products of the gas-phase $\mathrm{OH}$ and $\mathrm{NO}_{3}$ radicalinitiated reactions of naphthalene-d8, fluoranthene-d10, and pyrene, Int. J. Chem. Kinet., 22, 999-1014, 1990.

Atkinson, R. and Arey, J.: Atmospheric chemistry of gas-phase polycyclic aromatic hydrocarbons: formation of atmospheric mutagens, Environ. Health Perspect., 102, 117-126, 1994.

Bai, Z., Hu, Y., Yu, H., Wu, N., and You, Y.: Quantitative health risk assessment of inhalation exposure to polycyclic aromatic hydrocarbons on citizens in Tianjin, China, B. Environ. Contam. Tox., 83, 151-154, https://doi.org/10.1007/s00128-009-9686-8, 2009.

Bamford, H. A. and Baker, J. E.: Nitro-polycyclic aromatic hydrocarbon concentrations and sources in urban and suburban atmospheres of the Mid-Atlantic region, Atmos. Environ., 37, 20772091, https://doi.org/10.1016/S1352-2310(03)00102-X, 2003.

Bandowe, B. A. M., Meusel, H., Huang, R. J., Ho, K., Cao, J., Hoffmann, T., and Wilcke, W.: $\mathrm{PM}_{2.5}$-bound oxygenated PAHs, nitro-PAHs and parent-PAHs from the atmosphere of a Chinese megacity: Seasonal variation, sources and cancer risk assessment, Sci. Total Environ., 473-474, 77-87, https://doi.org/10.1016/j.scitotenv.2013.11.108, 2014.

Bange, H.: Gaseous Nitrogen Compounds $\left(\mathrm{NO}, \mathrm{N}_{2} \mathrm{O}, \mathrm{N}_{2}, \mathrm{NH}_{3}\right)$ in the Ocean in Nitrogen in the Marine Environment, Chapter 2, Second Edition, 51-94, 2008.

Benbrahim-Tallaa, L., Baan, R. A., Grosse, Y., Lauby-Secretan, B., El Ghissassi, F., Bouvard, V., Guha, N., Loomis, D., and Straif, K.: Carcinogenicity of diesel-engine and gasoline-engine exhausts and some nitroarenes, Lancet. Oncol., 13, 663-664, https://doi.org/10.1016/S1470-2045(12)70280-2, 2012.

Bezabeh, D. Z., Bamford, H. A., Schantz, M. M., and Wise, S. A.: Determination of nitrated polycyclic aromatic hydrocarbons in diesel particulate-related standard reference materials by using gas chromatography/mass spectrometry with negative ion chemical ionization, Anal. Bioanal. Chem., 375, 381-388, https://doi.org/10.1007/s00216-002-1698-8, 2003.

Bond, T. C., Streets, D. G., Yarber, K. F., Nelson, S. M., Woo, J. H., and Klimont, Z.: A technology-based global inventory of black and organic carbon emissions from combustion, J. Geophys. Res., 109, D14203, https://doi.org/10.1029/2003JD003697, 2004.

Chen, S. C. and Liao, C. M.: Health risk assessment on human exposed to environmental polycyclic aromatic hydrocarbons pollution sources, Sci. Total Environ., 366, 112-123, https://doi.org/10.1016/j.scitotenv.2005.08.047, 2006.

Chen, Y., Li, X., Zhu, T., Han, Y., and Lv, D.: PM 2.5 -bound PAHs in three indoor and one outdoor air in Beijing: Concentration, source and health risk assessment, Sci. Total Environ., 586, 255264, https://doi.org/10.1016/j.scitotenv.2017.01.214, 2017.

Chiang, H. L., Lai, Y. M., and Chang, S. Y.: Pollutant constituents of exhaust emitted from light-duty diesel vehicles, Atmos. Environ., 47, 399-406, https://doi.org/10.1016/j.atmosenv.2011.10.045, 2012.

Ciccioli, P., Cecinato, A., Brancaleoni, E., Frattoni, M., Zacchei, P., and Miguel, A. H.: Formation and transport of 2-nitrofluoranthene and 2-nitropyrene of photochemical ori- 
gin in the troposphere, J. Geophys. Res., 101, 19567-19581, https://doi.org/10.1029/95JD02118, 1996.

Dimashki, M., Harrad, S., and Harrison, R. M.: Measurements of nitro-PAH in the atmospheres of two cities, Atmos. Environ., 34, 2459-2469, https://doi.org/10.1016/S1352-2310(99)004173, 2000 .

Durant, J. L., Busby, W. F., Lafleur, A. L., Penman, B. W., and Crespi, C. L.: Human cell mutagenicity of oxygenated, nitrated and unsubstituted polycyclic aromatic hydrocarbons associated with urban aerosols, Mutat. Res. Genet. Toxicol., 371, 123-157, https://doi.org/10.1016/S0165-1218(96)90103-2, 1996.

Farren, N. J., Ramírez, N., Lee, J. D., Finessi, E., Lewis, A. C., and Hamilton, J. F.: Estimated Exposure Risks from Carcinogenic Nitrosamines in Urban Airborne Particulate Matter, Environ. Sci. Technol., 49, 9648-9656, https://doi.org/10.1021/acs.est.5b01620, 2015.

Feng, J., Chan, C. K., Fang, M., Hu, M., He, L., and Tang, X.: Impact of meteorology and energy structure on solvent extractable organic compounds of $\mathrm{PM}_{2.5}$ in Beijing, China, Chemosphere, 61, 623-632, https://doi.org/10.1016/j.chemosphere.2005.03.067, 2005.

Feng, B., Li, L., Xu, H., Wang, T., Wu, R., Chen, J., Zhang, Y., Liu, S., Ho, S. S. H., Cao, J., and Huang, W.: PM 2.5 -bound polycyclic aromatic hydrocarbons (PAHs) in Beijing: Seasonal variations, sources, and risk assessment, J. Environ. Sci., 77, 11-19, https://doi.org/10.1016/j.jes.2017.12.025, 2019.

Gao, Y. and Ji, H.: Characteristics of polycyclic aromatic hydrocarbons components in fine particle during heavy polluting phase of each season in urban Beijing, Chemosphere, 212, 346-357, https://doi.org/10.1016/j.chemosphere.2018.08.079, 2018.

Garrido-Frenich, A., Romero-González, R., Martínez-Vidal, J. L., Plaza-Bolaños, P., Cuadros-Rodríguez, L., and Herrera-Abdo, M. A.: Characterization of recovery profiles using gas chromatography-triple quadrupole mass spectrometry for the determination of pesticide residues in meat samples, J. Chromatogr. A, 1133, 315-321, https://doi.org/10.1016/j.chroma.2006.08.039, 2006.

Goriaux, M., Jourdain, B., Temime, B., Besombes, J.-L., Marchand, N., Albinet, A., Leoz-Garziandia, E., and Wortham, H.: Field Comparison of Particulate PAH Measurements Using a Low-Flow Denuder Device and Conventional Sampling Systems, Environ. Sci. Technol., 40, 6398-6404, https://doi.org/10.1021/es060544m, 2006.

Hamra, G. B., Guha, N., Cohen, A., Laden, F., Raaschou-Nielsen, O., Samet, J. M., Vineis, P., Forastiere, F., Saldiva, P., Yorifuji, T., and Loomis, D.: Outdoor particulate matter exposure and lung cancer: a systematic review and meta-analysis, Environ. Health. Perspect., 122, 906-911, https://doi.org/10.1289/ehp.1408092, 2014.

Hannigan, M. P., Cass, G. R., Penman, B. W., Crespi, C. L., Lafleur, A. L., Busby, W. F., Thilly, W. G., and Simoneit, B. R. T.: Bioassay-directed chemical analysis of los angeles airborne particulate matter using a human cell mutagenicity assay, Environ. Sci. Technol., 32, 3502-3514, 1998.

Jakober, C. A., Riddle, S. G., Robert, M. A., Destaillats, H., Charles, M. J., Green, P. G., and Kleeman, M. J.: Quinone Emissions from Gasoline and Diesel Motor Vehicles, Environ. Sci. Technol., 41, 4548-4554, https://doi.org/10.1021/es062967u, 2007.
Janhäll, S., Jonsson, Å. M., Molnár, P., Svensson, E. A., and Hallquist, M.: Size resolved traffic emission factors of submicrometer particles, Atmos. Environ., 38, 4331-4340, https://doi.org/10.1016/j.atmosenv.2004.04.018, 2004.

Jariyasopit, N., McIntosh, M., Zimmermann, K., Arey, J., Atkinson, R., Cheong, P. H.-Y., Carter, R. G., Yu, T.-W., Dashwood, R. H., and Massey Simonich, S. L.: Novel Nitro-PAH Formation from Heterogeneous Reactions of PAHs with $\mathrm{NO}_{2}$, $\mathrm{NO}_{3} / \mathrm{N}_{2} \mathrm{O}_{5}$, and $\mathrm{OH}$ Radicals: Prediction, Laboratory Studies, and Mutagenicity, Environ. Sci. Technol., 48, 412-419, https://doi.org/10.1021/es4043808, 2014.

Jia, Y., Stone, D., Wang, W., Schrlau, J., Tao, S., and Simonich, S. L.: Estimated reduction in cancer risk due to PAH exposures if source control measures during the 2008 Beijing Olympics were sustained, Environ. Health. Perspect., 119, 815-820, 2011.

Kawanaka, Y., Sakamoto, K., Wang, N., and Yun, S.-J.: Simple and sensitive method for determination of nitrated polycyclic aromatic hydrocarbons in diesel exhaust particles by gas chromatography-negative ion chemical ionisation tandem mass spectrometry, J. Chromatogr. A, 1163, 312-317, https://doi.org/10.1016/j.chroma.2007.06.038, 2007.

Keyte, I. J., Harrison, R. M., and Lammel, G.: Chemical reactivity and long-range transport potential of polycyclic aromatic hydrocarbons - a review, Chem. Soc. Rev., 42, 9333-9391, https://doi.org/10.1039/C3CS60147A, 2013.

Keyte, I. J., Albinet, A., and Harrison, R. M.: On-road traffic emissions of polycyclic aromatic hydrocarbons and their oxy- and nitro- derivative compounds measured in road tunnel environments, Sci. Total. Environ., 566-567, 1131-1142, https://doi.org/10.1016/j.scitotenv.2016.05.152, 2016.

Kim, K. H., Jahan, S. A., Kabir, E., and Brown, R. J. C.: A review of airborne polycyclic aromatic hydrocarbons (PAHs) and their human health effects, Environ. Int., 60, 71-80, https://doi.org/10.1016/j.envint.2013.07.019, 2013.

Larsen, J. C. and Larsen, P. B.: Chemical Carcinogens, in: Air pollution and Health, Volume 10 of Issues in environmental science and technology, edited by: Hester, R. E. and Harrison, R. M., Royal Society of Chemistry, United Kingdom, 33-56, https://doi.org/10.1039/9781847550095, 1998.

Lee, C., Martin, Randal., Donkelaar, A. V., Lee, H., Dickerson, R. R., Hains, J. C., Krotkov, N., Richter, A., Vinnikov, K., and Schwab, J. J.: $\mathrm{SO}_{2}$ emissions and lifetimes: Estimates from inverse modeling using in situ and global, space-based (SCIAMACHY and OMI) observations, J. Geophys. Res., 116, D06304, https://doi.org/10.1029/2010JD014758, 2011.

Lin, Y., Zou, J., Yang, W., and Li, C. Q.: A Review of Recent Advances in Research on $\mathrm{PM}_{2.5}$ in China, Int. J. Environ. Res. Public. Health., 15, 438, https://doi.org/10.3390/ijerph15030438, 2018.

Liu, J., Man, R., Ma, S., Li, J., Wu, Q., and Peng, J.: Atmospheric levels and health risk of polycyclic aromatic hydrocarbons (PAHs) bound to $\mathrm{PM}_{2.5}$ in Guangzhou, China, Mar. Pollut. Bull., 100, 134-143, https://doi.org/10.1016/j.marpolbul.2015.09.014, 2015.

Liu, Y., Tao, S., Yang, Y., Dou, H., Yang, Y., and Coveney, R. M.: Inhalation exposure of traffic police officers to polycyclic aromatic hydrocarbons (PAHs) during the winter in Beijing, China, Sci. Total Environ., 383, 98-105, https://doi.org/10.1016/j.scitotenv.2007.05.008, 2007. 
Marr, L. C., Grogan, L. A., Wöhrnschimmel, H., Molina, L. T., and Molina, M. J.: Vehicle Traffic as a Source of Particulate Polycyclic Aromatic Hydrocarbon Exposure in the Mexico City Metropolitan Area, Environ. Sci. Technol., 38, 2584-2592, https://doi.org/10.1021/es034962s, 2004.

Ministry of Ecology and Environment The People's Republic of China: Ambient air quality standards (GB-3095-2012), available at: http://english.mee.gov.cn/Resources/standards/Air_ Environment/quality_standard1/201605/t20160511_337502. shtml (last access: 3 July 2019), 2012.

Ministry of Ecology and Environment The People's Republic of China: Beijing toughens pollution rules for cleaner air, available at: http://english.mee.gov.cn/News_service/media_news/ 201309/t20130903_259454.shtml, (last access: 3 July 2019), 2013.

Nalin, F., Golly, B., Besombes, J. L., Pelletier, C., Aujay-Plouzeau, R., Verlhac, S., Dermigny, A., Fievet, A., Karoski, N., Dubois, P., Collet, S., Favez, O., and Albinet, A.: Fast oxidation processes from emission to ambient air introduction of aerosol emitted by residential log wood stoves, Atmos. Environ., 143, 15-26, https://doi.org/10.1016/j.atmosenv.2016.08.002, 2016.

Nisbet, I. C. T. and LaGoy, P. K.: Toxic equivalency factors (TEFs) for polycyclic aromatic hydrocarbons (PAHs), Regul. Toxicol. Pharmacol., 16, 290-300, https://doi.org/10.1016/02732300(92)90009-X, 1992.

Niu, X., Ho, S. S. H., Ho, K. F., Huang, Y., Sun, J., Wang, Q., Zhou, Y., Zhao, Z., and Cao, J.: Atmospheric levels and cytotoxicity of polycyclic aromatic hydrocarbons and oxygenated-PAHs in $\mathrm{PM}_{2.5}$ in the Beijing-Tianjin-Hebei region, Environ. Pollut., 231, 1075-1084, https://doi.org/10.1016/j.envpol.2017.08.099, 2017.

Nyiri, Z., Novák, M., Bodai, Z., Szabó, B. S., Ekea, Z., Zárayc, G., and Szigeti, T.: Determination of particulate phase polycyclic aromatic hydrocarbons and their nitrated and oxygenated derivatives using gas chromatography-mass spectrometry and liquid chromatography-tandem mass spectrometry, J. Chromatogr. A, 1472, 88-98, https://doi.org/10.1016/j.chroma.2016.10.021, 2016.

OEHHA (Office of Environmental Health Hazard Assessment): Benzo[a]pyrene as a Toxic Air Contaminant, available at: https://oehha.ca.gov/media/downloads/air/document/ benzo5ba5dpyrene.pdf (last access: 3 July 2019), 1994.

OEHHA (Office of Environmental Health Hazard Assessment): Air Toxics Hot Spots Program Risk Assessment Guidelines, Part II: Technical Support Document for Describing Available Cancer Potency Factors, Office of Environmental Health Hazard Assessment, available at: https://oehha.ca.gov/media/downloads/crnr/ tsdnov2002.pdf (last access: 3 July 2019), 105-109, 2002.

OEHHA (Office of Environmental Health Hazard Assessment): Air Toxics Hot Spots Program Risk Assessment Guidelines, Part II: Technical Support Document for Describing Available Cancer Potency Factors, Office of Environmental Health Hazard Assessment, available at: https://oehha.ca.gov/media/downloads/crnr/ may2005hotspots.pdf (last access: 3 July 2019), p. 8, p. A1, 2005.

Peng, L., Zhao, C., Lin, Y., Zheng, X., Tie, X., and Chan, L. Y.: Analysis of carbon monoxide budget in North China, Chemosphere, 66, 1383-1389, https://doi.org/10.1016/j.chemosphere.2006.09.055, 2007.
Pietrogrande, M. C., Abbaszade, G., Schnelle-Kreis, J., Bacco, D., Mercuriali, M., and Zimmermann, R.: Seasonal variation and source estimation of organic compounds in urban aerosol of Augsburg, Germany, Environ. Pollut., 159, 18611868, https://doi.org/10.1016/j.envpol.2011.03.023, 2011.

Pio, C. A., Alves, C. A., and Duarte, A. C.: Identification, abundance and origin of atmospheric organic particulate matter in a Portuguese rural area, Atmos. Environ., 35, 1365-1375, https://doi.org/10.1016/S1352-2310(00)00391-5, 2001.

Poulain, L., Iinuma, Y., Müller, K., Birmili, W., Weinhold, K., Brüggemann, E., Gnauk, T., Hausmann, A., Löschau, G., Wiedensohler, A., and Herrmann, H.: Diurnal variations of ambient particulate wood burning emissions and their contribution to the concentration of Polycyclic Aromatic Hydrocarbons (PAHs) in Seiffen, Germany, Atmos. Chem. Phys., 11, 12697-12713, https://doi.org/10.5194/acp-11-12697-2011, 2011.

Purohit, V. and Basu, A. K.: Mutagenicity of Nitroaromatic Compounds, Chem. Res. Toxicol., 13, 673-692, 2000.

Raaschou-Nielsen, O., Andersen, Z. J., Beelen, R., Samoli, E., Stafoggia, M., Weinmayr, G., Hoffmann, B., Fischer, P., Nieuwenhuijsen, M. J., Brunekreef, B., Xun, W. W., Katsouyanni, K., Dimakopoulou, K., Sommar, J., Forsberg, B., Modig, L., Oudin, A., Oftedal, B., Schwarze, P. E., Nafstad, P., De Faire, U., Pedersen, N. L., Ostenson, C. G., Fratiglioni, L., Penell, J., Korek, M., Pershagen, G., Eriksen, K. T., Sørensen, M., Tjønneland, A., Ellermann, T., Eeftens, M., Peeters, P. H., Meliefste, K., Wang, M., Bueno-de-Mesquita, B., Key, T. J., De Hoogh, K., Concin, H., Nagel, G., Vilier, A., Grioni, S., Krogh, V., Tsai, M. Y., Ricceri, F., Sacerdote, C., Galassi, C., Migliore, E., Ranzi, A., Cesaroni, G., Badaloni, C., Forastiere, F., Tamayo, I., Amiano, P., Dorronsoro, M., Trichopoulou, A., Bamia, C., Vineis, P., and Hoek, G.: Air pollution and lung cancer incidence in 17 European cohorts: prospective analyses from the European Study of Cohorts for Air Pollution Effects (ESCAPE), Lancet. Oncol., 14, 813-822, https://doi.org/10.1016/S14702045(13)70279-1, 2013.

Ramdahl, T., Zielinska, B., Arey, J., Atkinson, R., Winer, A. M., and Pitts, J. N.: Ubiquitous occurrence of 2-nitrofluoranthene and 2nitropyrene in air, Nature, 321, 425-427, 1986.

Ramírez, N., Cuadras, A., Rovira, Enric., Marcé, R. M., and Borrull, F.: Risk Assessment Related to Atmospheric Polycyclic Aromatic Hydrocarbons in Gas and Particle Phases near Industrial Sites, Environ. Health Persp., 119, 1110-1116, https://doi.org/10.1289/ehp.1002855, 2011.

Ramírez, N., Vallecillos, L., Lewis, A. C., Borrull, F., Marcé, R. M., and Hamilton, J. F.: Comparative study of comprehensive gas chromatography-nitrogen chemiluminescence detection and gas chromatography-ion trap-tandem mass spectrometry for determining nicotine and carcinogen organic nitrogen compounds in thirdhand tobacco smoke, J. Chromatogr. A, 1426, 191200, https://doi.org/10.1016/j.chroma.2015.11.035, 2015.813822, https://doi.org/10.1016/S1470-2045(13)70279-1, 2013.

Ravindra, K., Sokhi, R., and Van Grieken, R.: Atmospheric polycyclic aromatic hydrocarbons: Source attribution, emission factors and regulation, Atmos. Environ., 42, 2895-2921, https://doi.org/10.1016/j.atmosenv.2007.12.010, 2008.

Reisen, F. and Arey, J.: Atmospheric reactions influence seasonal PAH and nitro-PAH concentrations in the 
Los Angeles basin, Environ. Sci. Technol., 39, 64-73, https://doi.org/10.1021/es0354541, 2004.

Ringuet, J., Albinet, A., Leoz-Garziandia, E., Budzinski, H., and Villenave, E.: Reactivity of polycyclic aromatic compounds (PAHs, NPAHs and OPAHs) adsorbed on natural aerosol particles exposed to atmospheric oxidants, Atmos. Environ., 61, 1522, https://doi.org/10.1016/j.atmosenv.2012.07.025, 2012a.

Ringuet, J., Albinet, A., Leoz-Garziandia, E., Budzinski, H., and Villenave, E.: Diurnal/nocturnal concentrations and sources of particulate-bound PAHs, OPAHs and NPAHs at traffic and suburban sites in the region of Paris (France), Sci. Total Environ., 437, 297-305, doi.org/10.1016/j.scitotenv.2012.07.072, 2012 b.

Riva, M., Healy, R. M., Flaud, P. M., Perraudin, E., Wenger, J. C., and Villenave, E.: Gas- and Particle-Phase Products from the Chlorine-Initiated Oxidation of Polycyclic Aromatic Hydrocarbons, J. Phys. Chem. A., 119, 11170-11181, https://doi.org/10.1021/acs.jpca.5b04610, 2015.

Rogge, W. F., Hildemann, L. M., Mazurek, M. A., Cass, G. R., and Simoneit, B. R. T.: Sources of fine organic aerosol. 2. Noncatalyst and catalyst-equipped automobiles and heavyduty diesel trucks, Environ. Sci. Technol., 27, 636-651, https://doi.org/10.1021/es00041a007, 1993.

Saikawa, E., Naik, V., Horowitz, L. W., Liu, J. F., and Mauzerall, D. L.: Present and potential future contributions of sulfate, black and organic carbon aerosols from China to global air quality, premature mortality and radiative forcing, Atmos. Environ., 43, 28142822, https://doi.org/10.1016/j.atmosenv.2009.02.017, 2009.

Sasaki, J., Aschmann, S. M., Kwok, E. S. C., Atkinson, R., and Arey, J.: Products of the gas-phase $\mathrm{OH}$ and $\mathrm{NO}_{3}$ radical-initiated reactions of naphthalene, Environ. Sci. Technol., 31, 3173-3179, 1997.

Schauer, C., Neissner, R., and Pöschl, U.: Polycyclic Aromatic Hydrocarbons in Urban Air Particulate Matter: Decadal and Seasonal Trends, Chemical Degradation, and Sampling Artifacts, Environ. Sci. Technol., 37, 2861-2868, https://doi.org/10.1021/es034059s, 2003.

Schulte, J. K., Fox, J. R., Oron, A. P., Larson, T. V., Simpson, C. D., Paulsen, M., Beaudet, N., Kaufman, J. D., and Magzamen, S.: Neighborhood-scale spatial models of diesel exhaust concentration profile using 1-nitropyrene and other nitroarenes, Environ. Sci. Technol., 49, 13422-13430, https://doi.org/10.1021/acs.est.5b03639, 2015.

Sharma, H., Jain, V. K., and Khan, Z. H.: Characterization and source identification of polycyclic aromatic hydrocarbons (PAHs) in the urban environment of Delhi, Chemosphere, 66, 302-310, https://doi.org/10.1016/j.chemosphere.2006.05.003, 2007.

Shen, G., Tao, S., Wei, S., Zhang, Y., Wang, R., Wang, B., Li, W., Shen, H., Huang, Y., Chen, Y., Chen, H., Yang, Y., Wang, W., Wang, X., Liu, W., and Simonich, S. L. M.: Emissions of parent, nitro, and oxygenated polycyclic aromatic hydrocarbons from residential wood combustion in rural China, Environ. Sci. Technol., 46, 8123-8130, https://doi.org/10.1021/es301146v, 2012.

Song, H., Zhang, Y., Luo, M., Gu, J., Wu, M., Xu, D., Xu, G., and Ma, L.: Seasonal variation, sources and health risk assessment of polycyclic aromatic hydrocarbons in different particle fractions of $\mathrm{PM}_{2.5}$ in Beijing, China, Atmos. Pollut. Res., 10, 105-114, https://doi.org/10.1016/j.apr.2018.06.012, 2019.
Srivastava, D., Favez, O., Bonnaire, N., Lucarelli, F., Haeffelin, M., Perraudin, E., Gros, V., Villenave, E., and Albinet, A.: Speciation of organic fractions does matter for aerosol source apportionment. Part 2: Intensive short-term campaign in the Paris area (France), Sci. Total Environ., 634, 267-278, https://doi.org/10.1016/j.scitotenv.2018.03.296, 2018.

Tian, Y., Xiao, Z., Wang, H., Peng, X., Guan, L., Huangfu, Y., Shi, G., Chen, K., Bi, X., and Feng, Y.: Influence of the sampling period and time resolution on the PM source apportionment: Study based on the high time-resolution data and long-term daily data, Atmos. Environ., 165, 301-309, https://doi.org/10.1016/j.atmosenv.2017.07.003, 2017.

Tobiszewski, M. and Namieśnik, J.: PAH diagnostic ratios for the identification of pollution emission sources, Environ. Pollut., 162, 110-119, https://doi.org/10.1016/j.envpol.2011.10.025, 2012.

Tomaz, S., Shahpoury, P., Jaffrezo, J.-L., Lammel, G., Perraudin, E., Villenave, E., and Albinet, A.: One-year study of polycyclic aromatic compounds at an urban site in Grenoble (France): Seasonal variations, gas/particle partitioning and cancer risk estimation, Sci. Total Environ., 565, 1071-1083, https://doi.org/10.1016/j.scitotenv.2016.05.137, 2016.

Tomaz, S., Jaffrezo, J.-L., Favez, O., Perraudin, E., Villenave, E., and Albinet, A.: Sources and atmospheric chemistry of oxy- and nitro-PAHs in the ambient air of Grenoble (France), Atmos. Environ., 161, 144-154, https://doi.org/10.1016/j.atmosenv.2017.04.042, 2017.

Tsapakis, M. and Stephanou, E. G.: Collection of gas and particle semi-volatile organic compounds: use of an oxidant denuder to minimize polycyclic aromatic hydrocarbons degradation during high-volume air sampling, Atmos. Environ., 37, 4935-4944, https://doi.org/10.1016/j.atmosenv.2003.08.026, 2003.

Tsapakis, M. and Stephanou, E. G: Diurnal Cycle of PAHs, NitroPAHs, and oxy-PAHs in a High Oxidation Capacity Marine Background Atmosphere, Environ. Sci. Technol., 41, 80118017, https://doi.org/10.1021/es071160e, 2007.

Wang, G., Kawamura, K., Lee, S., Ho, K., and Cao, J.: Molecular, Seasonal, and Spatial Distributions of Organic Aerosols from Fourteen Chinese Cities, Environ. Sci. Technol., 40, 4619-4625, https://doi.org/10.1021/es060291x, 2006.

Wang, W., Jariyasopit, N., Schrlau, J., Jia, Y., Tao, S., Yu, T. W., Dashwood, R. H., Zhang, W., Wang, X., and Simonich, S. L. M.: Concentration and Photochemistry of PAHs, NPAHs, and OPAHs and Toxicity of $\mathrm{PM}_{2.5}$ during the Beijing Olympic Games, Environ. Sci. Technol., 45, 6887-6895, https://doi.org/10.1021/es201443z, 2011a.

Wang, W., Huang, M. J., Kang, Y., Wang, H. S., Leung, A. O. W., Cheung, K. C., and Wong, M. H.: Polycyclic aromatic hydrocarbons (PAHs) in urban surface dust of Guangzhou, China: Status, sources and human health risk assessment, Sci. Total Environ., 409, 4519-4527, https://doi.org/10.1016/j.scitotenv.2011.07.030, 2011 b.

Wang, W., Simonich, S. L. M., Wang, W., Giri, B., Zhao, J., Xue, M., Cao, J., Lu, X., and Tao, S.: Atmospheric polycyclic aromatic hydrocarbon concentrations and gas/particle partitioning at background, rural village and urban sites in the North China Plain, Atmos. Res., 99, 197-206, https://doi.org/10.1016/j.atmosres.2010.10.002, 2011c. 
Wei, C., Bandowe, B. A. M., Han, Y., Cao, J., Zhan, C., and Wilcke, W.: Polycyclic aromatic hydrocarbons (PAHs) and their derivatives (alkyl-PAHs, oxygenatedPAHs, nitrated-PAHs and azaarenes) in urban road dusts from Xi'an, Central China, Chemosphere, 134, 512-520, https://doi.org/10.1016/j.chemosphere.2014.11.052, 2015.

Wenyuan, C. and Zhu, T.: Formation of Nitroanthracene and Anthraquinone from the Heterogeneous Reaction Between $\mathrm{NO}_{2}$ and Anthracene Adsorbed on $\mathrm{NaCl}$ Particles, Environ. Sci. Technol., 48, 8671-8678, https://doi.org/10.1021/es501543g, 2014.

WHO (World Health Organization): Air Quality Guidelines for Europe, 2nd ed., Copenhagen, WHO, Regional Office for Europe (Copenhagen), available at: http://www.euro.who. int/_data/assets/pdf_file/0005/74732/E71922.pdf (last access: 3 July 2019), Chapter 5, 92-94, 2000.

WHO (World Health Organization): outdoor air pollution, IARC Monographs on the Evaluation of Carcinogenic Risks to Humans, International Agency for Research on Cancer, 109, Lyon, France, 2016.

Wu, Y., Yang, L., Zheng, X., Zhang, S., Song, S., Li, J., and Hao, J.: Characterization and source apportionment of particulate PAHs in the roadside environment in Beijing, Sci. Total Environ., 470471, 76-83, https://doi.org/10.1016/j.scitotenv.2013.09.066, 2014.

Xu, S. S., Liu, W. X., and Tao, S.: Emission of polycyclic aromatic hydrocarbons in China, Environ. Sci. Technol., 40, 702708, https://doi.org/10.1021/es0517062, 2006.
Yunker, M. B., Macdonald, R. W., Vingarzanc, R., Mitchell, R. H., Goyette, D., and Sylvestre, S.: PAHs in the Fraser River basin: a critical appraisal of $\mathrm{PAH}$ ratios as indicators of PAH source and composition, Org. Geochem., 33, 489-515, https://doi.org/10.1016/S0146-6380(02)00002-5, 2002.

Zhang, J., Yang, L., Mellouki, A., Chen, J., Chen, X., Gao, Y., Jiang, P., Li, Y., Yu, H., and Wang, W.: Atmospheric PAHs, NPAHs, and OPAHs at an urban, mountainous, and marine sites in Northern China: Molecular composition, sources, and ageing, Atmos. Environ., 173, 256-264, https://doi.org/10.1016/j.atmosenv.2017.11.002, 2018.

Zhang, W., Tong, S., Ge, M., An, J., Shi, Z., Hou, S., Xia, K., Qu, Y., Zhang, H., Chu, B., Sun, Y., and He, H.: Variations and sources of nitrous acid (HONO) during a severe pollution episode in Beijing in winter 2016, Sci. Total Environ., 648, 253262, https://doi.org/10.1016/j.scitotenv.2018.08.133, 2019.

Zhang, Y. X. and Tao, S.: Global atmospheric emission inventory of polycyclic aromatic hydrocarbons (PAHs) for 2004, Atmos. Environ., 43, 812-819, https://doi.org/10.1016/j.atmosenv.2008.10.050, 2009.

Zimmermann, K., Jariyasopit, N., Massey Simonich, S. L., Tao, S., Atkinson, R., and Arey, J.: Formation of Nitro-PAHs from the Heterogeneous Reaction of Ambient Particle-Bound PAHs with $\mathrm{N}_{2} \mathrm{O}_{5} / \mathrm{NO}_{3} / \mathrm{NO}_{2}$, Environ. Sci. Technol., 47, 8434-8442, https://doi.org/10.1021/es401789x, 2013. 